\title{
The SCOUT-O3 Darwin Aircraft Campaign: rationale and meteorology
}

\author{
D. Brunner ${ }^{1,2}$, P. Siegmund ${ }^{3}$, P. T. May $^{4}$, L. Chappel ${ }^{4}$, C. Schiller ${ }^{5}$, R. Müller ${ }^{5}$, T. Peter ${ }^{2}$, S. Fueglistaler ${ }^{2}$, \\ A. R. MacKenzie ${ }^{6}$, A. Fix ${ }^{7}$, H. Schlager ${ }^{7}$, G. Allen ${ }^{8}$, A. M. Fjaeraa ${ }^{9}$, M. Streibel ${ }^{10}$, and N. R. P. Harris ${ }^{10}$ \\ ${ }^{1}$ Empa, Swiss Federal Laboratories for Materials Testing and Research, Dübendorf, Switzerland \\ ${ }^{2}$ Institute for Atmospheric and Climate Science, ETH Zurich, Zurich, Switzerland \\ ${ }^{3}$ Royal Netherlands Meteorological Institute KNMI, De Bilt, The Netherlands \\ ${ }^{4}$ Bureau of Meteorology Research Centre, Melbourne, Australia \\ ${ }^{5}$ ICG-1, Forschungszentrum Jülich, Jülich, Germany \\ ${ }^{6}$ Environmental Science, Lancaster University, UK \\ ${ }^{7}$ DLR Institut für Physik der Atmosphäre, Oberpfaffenhofen, Germany \\ ${ }^{8}$ Centre for Atmospheric Science, University of Manchester, Manchester, UK \\ ${ }^{9}$ Atmosphere and Climate Change Department, NILU, Norway \\ ${ }^{10}$ European Ozone Research Coordinating Unit, University of Cambridge, Cambridge, UK
}

Received: 14 July 2008 - Published in Atmos. Chem. Phys. Discuss.: 11 September 2008

Revised: 8 December 2008 - Accepted: 9 December 2008 - Published: 8 January 2009

\begin{abstract}
An aircraft measurement campaign involving the Russian high-altitude aircraft M55 Geophysica and the German DLR Falcon was conducted in Darwin, Australia in November and December 2005 as part of the European integrated project SCOUT-O3. The overall objectives of the campaign were to study the transport of trace gases through the tropical tropopause layer (TTL), mechanisms of dehydration close to the tropopause, and the role of deep convection in these processes. In this paper a detailed roadmap of the campaign is presented, including rationales for each flight, and an analysis of the local and large-scale meteorological context in which they were embedded. The campaign took place during the pre-monsoon season which is characterized by a pronounced diurnal evolution of deep convection including a mesoscale system over the Tiwi Islands north of Darwin known as "Hector". This allowed studying in detail the role of deep convection in structuring the tropical tropopause region, in situ sampling convective overshoots above storm anvils, and probing the structure of anvils and cirrus clouds by Lidar and a suite of in situ instruments onboard the two aircraft. The large-scale flow during the first half of the campaign was such that local flights, away from convection, sam-
\end{abstract}

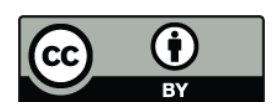

Correspondence to: D. Brunner (dominik.brunner@empa.ch) pled air masses downstream of the "cold trap" region over Indonesia. Abundant cirrus clouds enabled the study of active dehydration, in particular during two TTL survey flights. The campaign period also encompassed a Rossby wave breaking event transporting stratospheric air to the tropical middle troposphere and an equatorial Kelvin wave modulating tropopause temperatures and hence the conditions for dehydration.

\section{Introduction}

SCOUT-O3 is a European integrated project aiming at a better understanding of the link between stratospheric chemistry and, in particular, stratospheric ozone and climate change. In the framework of this project an aircraft measurement campaign was conducted in Darwin, Australia, during the premonsoon season from 12 November to 10 December 2005. The objectives of the campaign were to better understand (i) transport of trace gases through the tropical tropopause layer (TTL) and into the stratosphere, (ii) the role of deep convection in this transport, and (iii) the dehydration processes close to the tropical tropopause.

There is considerable evidence that the Indonesian/Western Pacific region or "Maritime Continent" plays a key role in troposphere-to-stratosphere transport

Published by Copernicus Publications on behalf of the European Geosciences Union. 
(TST) and associated dehydration processes. This prominent role is due to widespread high-reaching convection over the warm waters of the "Tropical Warm Pool" and concomitant exceptionally cold tropopause temperatures. According to the "stratospheric fountain" hypothesis of Newell and Gould-Stewart (1981), the Maritime Continent is a preferred region for TST. The very low tropopause temperatures in this "cold trap" region, and the associated freeze-drying through sedimentation of cirrus particles in air moving upward from the troposphere to the stratosphere, may explain the very low water vapor concentrations in the stratosphere. The presence of active freeze-drying is indeed supported by observations of subvisible cirrus clouds at tropopause level from the SAGE satellite instrument (Wang et al., 1996) showing a pronounced maximum in occurrence over this region. While the term "fountain" emphasizes the role of vertical motion, Holton and Gettelman (2001) and Gettelman et al. (2002) highlighted the importance of horizontal as opposed to vertical transport, which exposes air - circulating the globe and slowly ascending in the TTL - to the cold temperatures in this cold trap region. Similar conclusions were drawn by Bonazzola and Haynes (2004) and Fueglistaler et al. $(2004,2005)$ by means of trajectory calculations based on large-scale wind fields. They modeled freeze-drying in each air parcel undergoing TST by assuming its water partial pressure to relax to the equilibrium vapor pressure over ice at the lowest temperature encountered. They demonstrated this equilibrium approach to yield good agreement with measurements and to be consistent with observed seasonal and interannual variability.

An alternative hypothesis, "convective dehydration", postulates that dehydration occurs mainly in very deep, overshooting convection that would not be represented by the large-scale flow (e.g. Danielsen, 1982, 1993; Sherwood and Dessler, 2001). This mechanism invokes overshooting to lead to very dry air caused by the extremely low temperatures in cumulonimbus turrets. Other observational and model studies, however, suggest that overshooting convection rather hydrates than dehydrates the lower stratosphere (Kley et al., 1982; Chaboureau et al., 2007). Also in situ measurements performed over Hector within SCOUT-O3 provide evidence that this storm is hydrating, not dehydrating the TTL and the stratosphere to $2 \mathrm{~km}$ above the tropopause (Corti et al., 2008). Similar evidence for the presence of ice particles injected into the lowermost stratosphere by deep convective overshoots had been presented previously for the Hector system by Kelly et al. (1993) and for other tropical thunderstorms over Brasil by Nielsen et al. (2007).

The Lagrangian and Eulerian model studies by Fueglistaler et al. (2004) and Levine et al. (2007) suggest that the Maritime Continent acts as a fountain for the TTL - rather than for the stratosphere itself - in the sense that air in the global TTL is largely supplied by convective upward transport over this region. Transport into the stratosphere, conversely, may take place elsewhere, at least on the scales resolved by global model wind fields. Very short lived halogenated substances (VSLS) released in this region therefore have the largest potential to reach the TTL and eventually the stratosphere before being removed by chemical conversion and deposition (Levine et al., 2007). However, the relevance of the Maritime Continent for TST was recently questioned by Ricaud et al. (2007). They analyzed satellite observations of tropospheric trace gases in the tropical lower stratosphere for the season MarchApril-May during three years. They found that at least in this season the trace gas concentrations show pronounced maxima over continental regions, in particular over Africa, but not over Micronesia. Based on this they argued that direct injection into the stratosphere by deep overshooting convection over central continental regions provided an important mechanism for TST.

Darwin $\left(12^{\circ} 28^{\prime} \mathrm{S}, 130^{\circ} 51^{\prime} \mathrm{E}\right)$ is located at the northern tip of Australia known as the "Top End" (see Fig. 10 for location of Darwin and other geographic points referenced later). Owing to its location in the tropics at the southern border of the Tropical Warm Pool and its excellent infrastructure, Darwin has hosted a number of atmospheric research campaigns including the Maritime Continent Thunderstorm Experiment (MCTEX) (Keenan et al., 2000), the Down Under Doppler and Electricity Experiment (DUNDEE) (Rutledge et al., 1992), and more recently the EMERALD-2 campaign (Whiteway et al., 2004), and many others.

The Stratosphere-Troposphere-Exchange Project (STEP) had conducted a campaign in 1987 (Russell et al., 1993) with objectives similar to those of SCOUT-O3 though targeting at the monsoon season. The later start of STEP was, to some extent, due to diplomatic delays, and was a source of regret to those meteorologists who arrived ahead of the research aircraft witnessing the vigorous nature of pre-monsoon storms (Danielsen, 1993, p. 8665). During the pre-monsoon and monsoon breaks, a mesoscale deep convective system colloquially known as "Hector" develops almost daily over the Tiwi Islands some $100 \mathrm{~km}$ north of Darwin (Keenan and Carbone, 1992). It is triggered by island heating inducing lowlevel convergence of heat and moisture which is particularly concentrated along the sea-breeze fronts (Crook, 2001).

The high predictability of the Hector system was a major motivation for conducting the SCOUT-O3 campaign in Darwin. Complemented with an excellent ground infrastructure with a polarimetric radar, regular radiosondes, and the Atmospheric Radiation Monitoring (ARM) site, Darwin may be considered a "natural laboratory" for studies of tropical deep convection. It further hosts a regional forecasting center of the Australian Bureau of Meteorology (BoM) which generously supported the campaign by addressing specific questions during their regular briefings and providing access to real-time radar data and other analysis tools.

Conducting the campaign in Darwin offered the opportunity to sample Hectors simultaneously at four different altitudes through joint flights with the Aerosol and 
(a) October

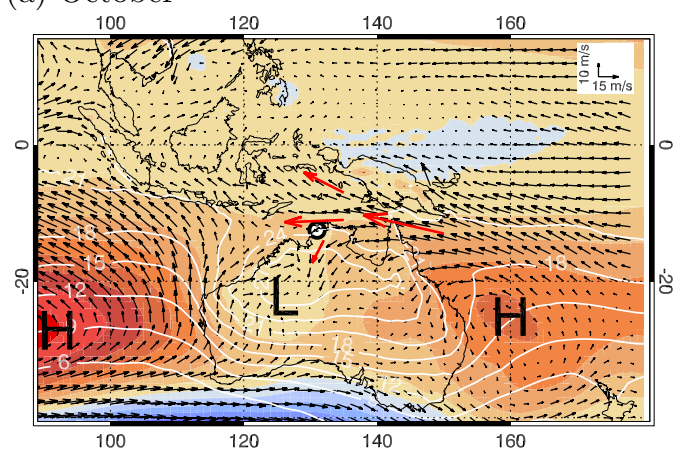

(c) December

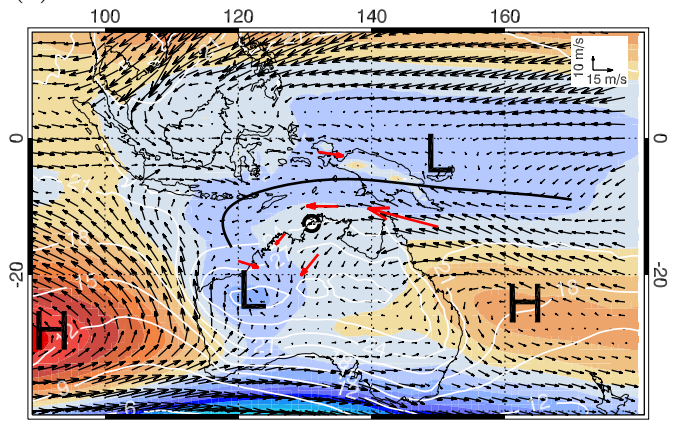

(b) November

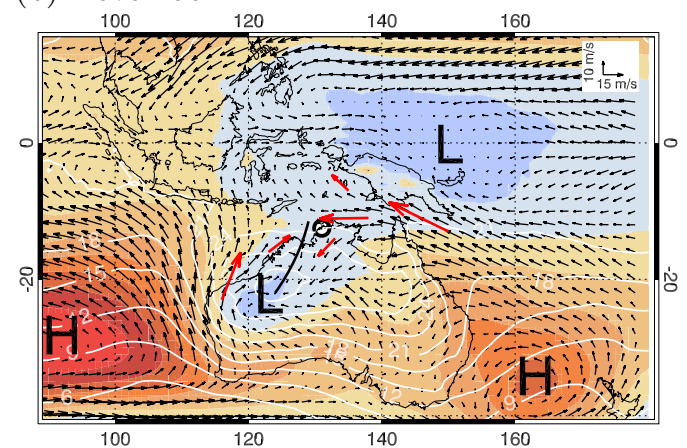

(d) January

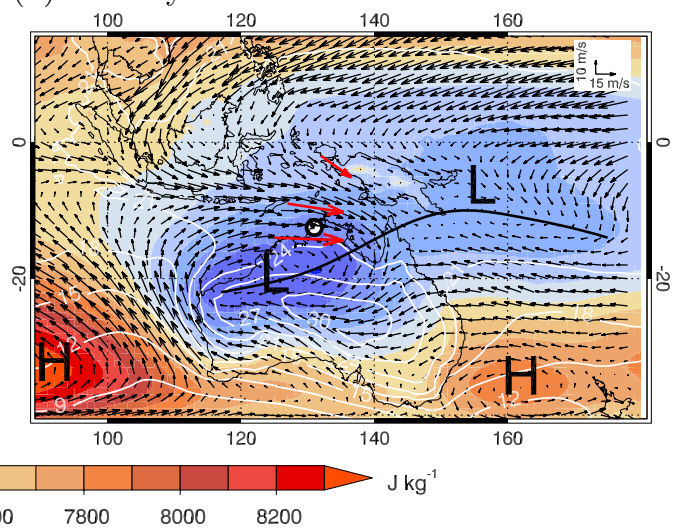

Fig. 1. Evolution of monthly mean geopotential $\left[\mathrm{J} \mathrm{kg}^{-1}\right]$ (color contours), winds (arrows) and temperature [ $\left.{ }^{\circ} \mathrm{C}\right]$ (white line contours) at $925 \mathrm{hPa}$ from October 2005 to January 2006 (ECWMF operational analyzes). The position of Darwin is indicated by the circle in panel (a). Red arrows are indicating particularly relevant features. Solid black lines indicate the positions of the main troughs.

Chemical Transport in Tropical Convection (ACTIVE) campaign (Vaughan et al., 2008), and to contrast pre-monsoon convection with the more organized and persistent but less vigourous monsoon systems (May and Ballinger, 2006) sampled two months later jointly by ACTIVE and the Tropical Warm Pool - International Cloud Experiment (TWP-ICE) (May et al., 2008b).

A general overview of the SCOUT-O3/ACTIVE field campaign was given by Vaughan et al. (2008). Beyond campaign logistics and a description of the payloads of the two SCOUT-O3 (Falcon and Geophysica) and the two ACTIVE aircraft (Dornier and Egrett), Vaughan et al. (2008) focused on the deployment of the aircraft during the two joint ACTIVE/SCOUT missions on 16 and 30 November. They also described the atmospheric features encountered during the transfer flights from Europe.

Here, a detailed roadmap of the SCOUT-O3 component is given, including rationales for each flight, and an analysis of the local and large-scale meteorological context in which they were embedded. Results based on the chemical and microphysical measurements will be presented in dedicated papers accompanying this special issue and will be referenced here where appropriate. A total of twelve legs were required to transfer the aircraft from Europe to Darwin and back. These flights constituted an essential element of the campaign but will not be treated here except for the two legs to and from Darwin.

To put the campaign into perspective, Sect. 2 discusses the large-scale meteorological situation in comparison with climatologies. Section 3 discusses the evolution of the local weather at Darwin with a focus on convection. Summaries of the individual flights including descriptions of mission aims, flight strategies, and meteorological situations are given in Sect. 4. Finally, Sect. 5 presents a brief analysis of the origin of air masses sampled during the campaign in the tropopause region.

\section{Large-scale meteorological context}

\subsection{Evolution of Australian monsoon and large-scale flow}

A summary of the large-scale tropical circulation in the Australian/Asian region covering the 2005/2006 Australian summer monsoon cycle (November 2005 to April 2006) is given in Shaik and Cleland (2006). The wet season in northern Australia typically starts in October with the pre-monsoon or 
(a) October

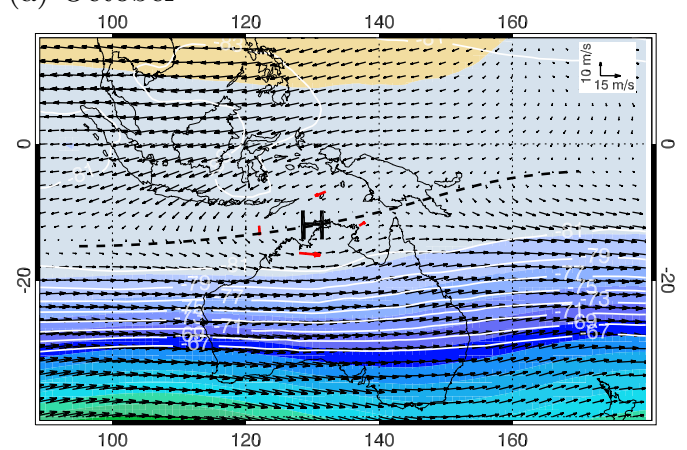

(c) December

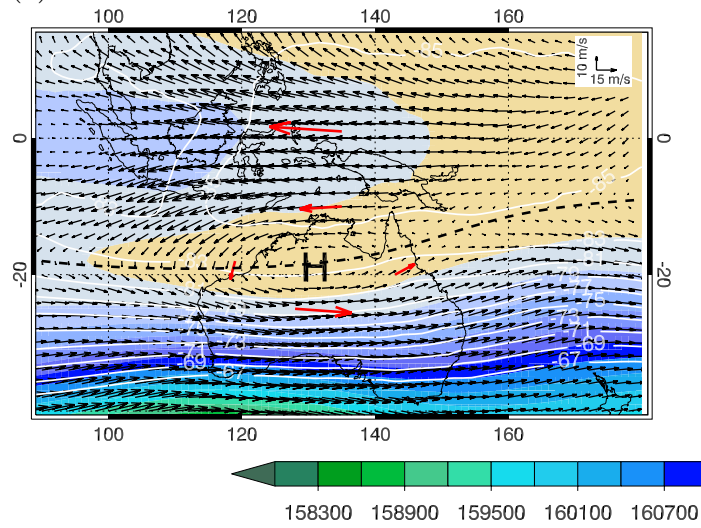

(b) November

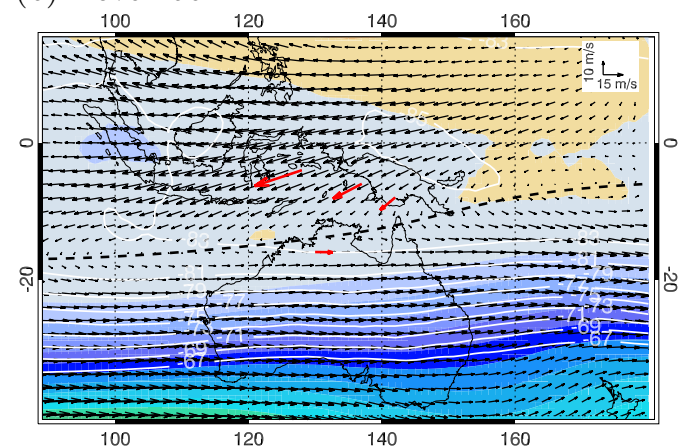

(d) January

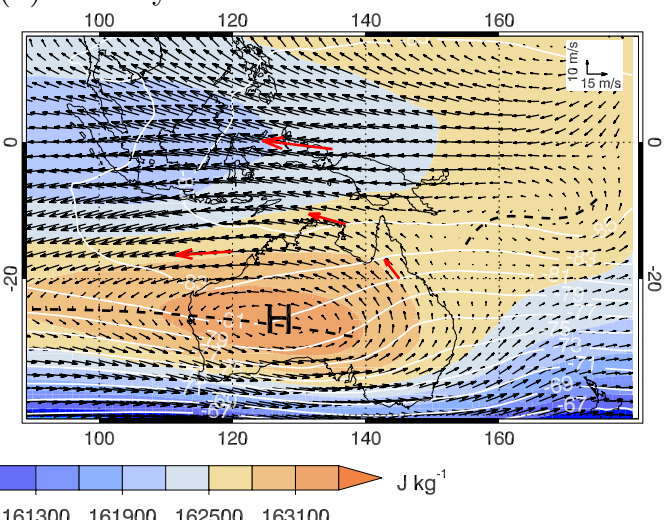

Fig. 2. Same as Fig. 1 but for $100 \mathrm{hPa}$. Dashed lines indicate the position of the upper level ridge.

"buildup" period characterized by easterly flow in the lower troposphere and a pronounced diurnal evolution of vigorous isolated storms and mesoscale systems of continental nature. The climatological mean date of the monsoon onset is 28 December but it may occur several weeks earlier or later in a given year. It manifests itself by a shift to a regime of deep westerlies and a change to more persistent but less vigorous storms of oceanic nature and little diurnal variation (Holland, 1986; Drosdowsky, 1996).

The evolution of the monsoon circulation from October 2005 to January 2006 is illustrated in Figs. 1 and 2 based on monthly mean fields of wind, geopotential and temperature for the lower $(925 \mathrm{hPa})$ and upper troposphere $(100 \mathrm{hPa})$, respectively. During the campaign in November and December, Darwin was located between the Australian summer heat low and the equatorial low pressure trough of the ITCZ (Fig. 1b). According to Shaik and Cleland (2006) the position of these troughs (marked " $\mathrm{L}$ " in the figure) and of the subtropical ridges ("H") was close to the climatological mean. At the $100 \mathrm{hPa}$ level, the temperature, wind and pressure fields reflect the large-scale planetary wave response to the latent heat release over the warm waters of the Tropical Warm Pool (Matsuno, 1966; Gill, 1980).

Convective activity intensifies considerably north of Australia from October to January when the center of tropical convection and latent heat release shifts from Burma/Thailand/Malaysia southeastward into Indonesia. The monsoon trough (a line of minimum pressure and maximum low-level convergence of horizontal wind and moisture, indicated by the solid black line) strengthens accordingly and moves southward eventually passing over Darwin. This passage of the trough marks the onset of the monsoon and the corresponding shift from an easterly to a westerly regime in the lower troposphere.

Weak easterly trade winds dominate near the surface $(925 \mathrm{hPa})$ at Darwin between October and December. In November 2005 (Fig. 1b), a trough axis extended from the Australian heat low towards Darwin as indicated by the black solid line, with easterly and westerly winds on its eastern and western side, respectively. Between about 19 and 23 November this axis was clearly established east of Darwin and low level winds changed to westerly as described later. In early December, the easterly wind regime was re-established and lasted until 13 January when the monsoon trough finally moved south of Darwin (Fig. 1d).

Characteristic for the thermally driven Hadley and Walker circulations, convergence in the trough regions at low levels is mirrored by divergence in upper level ridges in the upper troposphere at $100 \mathrm{hPa}$ (dashed lines in Fig. 2). During the fully fledged Australian monsoon in January, a large 
anticyclone is established over central and southwestern Australia overlying the surface heat low (Fig. 2d).

In November 2005, the axis of the upper level ridge was located close to Darwin causing relatively low and highly variable winds in the upper troposphere. Occasionally, an anticyclonic circulation embedded in the ridge was established over Northern Australia (as is visible in the October and December means). Depending on its exact position the flow could change direction completely from one day to another. In addition, depending on the position of the ridge axis, the origin of air masses changed significantly as will be shown in Sect. 5.

In December, the ridge moved southwards establishing an easterly upper level flow over Darwin which strengthened in January with the full establishment of the monsoon (Fig. 2c and d). This easterly flow was also the prevailing situation during the STEP campaign in 1987 (Russell et al., 1993; Danielsen, 1993). At even higher levels in the lower stratosphere the winds were generally easterly due to the QuasiBiennial-Oscillation (QBO) being in an easterly phase, again similar to the situation during STEP.

North-south cross-sections of the zonal mean wind component and temperature at the longitude of Darwin $\left(131^{\circ} \mathrm{E}\right)$ illustrate the vertical structure of the large-scale flow and the evolution of temperatures in the tropopause cold trap (Fig. 3). Only isolines for temperatures below the lowest temperatures observed at the mid-latitude tropopause (about $-67^{\circ} \mathrm{C}$ ) are shown to highlight the tropical upper troposphere. During the pre-monsoon (November/December) the monsoon trough (black solid line) was located north of Darwin. Consequently, the low level flow at Darwin was easterly. Easterlies prevailed throughout the troposphere and the lower stratosphere in December 2005 when the Southern Hemisphere subtropical jet was sufficiently far south, (Fig. 3b). In November (Fig. 3a), however, a series of Rossby wave breaking events caused a double jet structure (Fig. 3a) with the northern part extending towards the equator and inducing westerly winds between 400 and $100 \mathrm{hPa}$ over Darwin. During a few days these westerlies even extended into the lower troposphere. The easterly trades were thus not well established in November but low winds often dominated in the lower troposphere. In January, the monsoon trough was established south of Darwin (Fig. 3c). A deep layer of westerlies characteristic of the monsoon extended from the surface to about $300 \mathrm{hPa}$ changing to a pronounced easterly flow aloft due to the presence of the upper-level anticyclone (cf. Fig. 2d).

As indicated by the temperature contours, the tropopause cold trap region was quite broad extending from at least $10^{\circ} \mathrm{S}$ to $10^{\circ} \mathrm{N}$ centered on the equator. Cold point tropopause temperatures at Darwin were only about $1^{\circ}$ warmer than in the core region and were coldest in December and January with monthly means of about $-85^{\circ} \mathrm{C}$, close to the values reported by Selkirk (1993) for the STEP campaign.
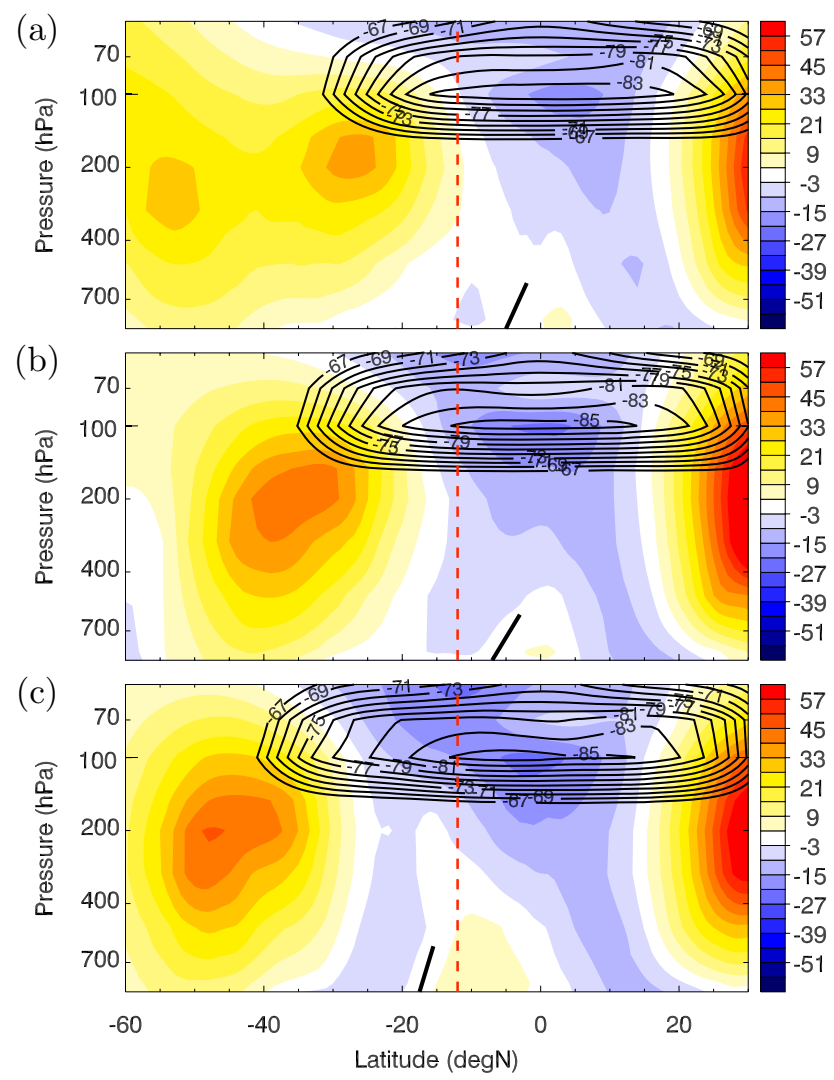

Fig. 3. North-south cross-sections of monthly mean zonal wind component $\mathrm{u}[\mathrm{m} / \mathrm{s}]$ (color contours) and temperatures below $-67^{\circ} \mathrm{C}$ (line contours) along $131^{\circ}$ E. (a) November 2005, (b) December 2005, (c) January 2006. Yellow to red contours indicate positive values (westerlies), bluish colors negative values (easterlies). The thick black solid line denotes the monsoon trough, the red dashed line the latitude of Darwin.

\subsection{Interannual and intraseasonal variability}

In order to judge the representativeness of the SCOUT-O3 measurements it is useful to evaluate the meteorological conditions with respect to interannual and intraseasonal variability. Interannual variability over northern Australia and Indonesia is dominated by the El Niño - Southern Oscillation (ENSO). The Southern Oscillation Index frequently used as a measure for ENSO indicates that the campaign took place under neutral to weak La Niña conditions (Shaik and Cleland, 2006). Intraseasonal variability is affected by various tropical waves and disturbances including the Madden Julian Oscillation (MJO; Madden and Julian, 1971; Wheeler and Hendon, 2004). Figure 4 presents a Hovmöller diagram of the evolution of outgoing long-wave radiation (OLR) anomalies (with respect to the 1979-2001 mean seasonal cycle) from October 2005 to March 2006 showing mildly negative values at the longitude of Darwin during SCOUT-O3 consistent with a weak La Niña. The diagram further suggests that the campaign was only little affected by tropical wave 


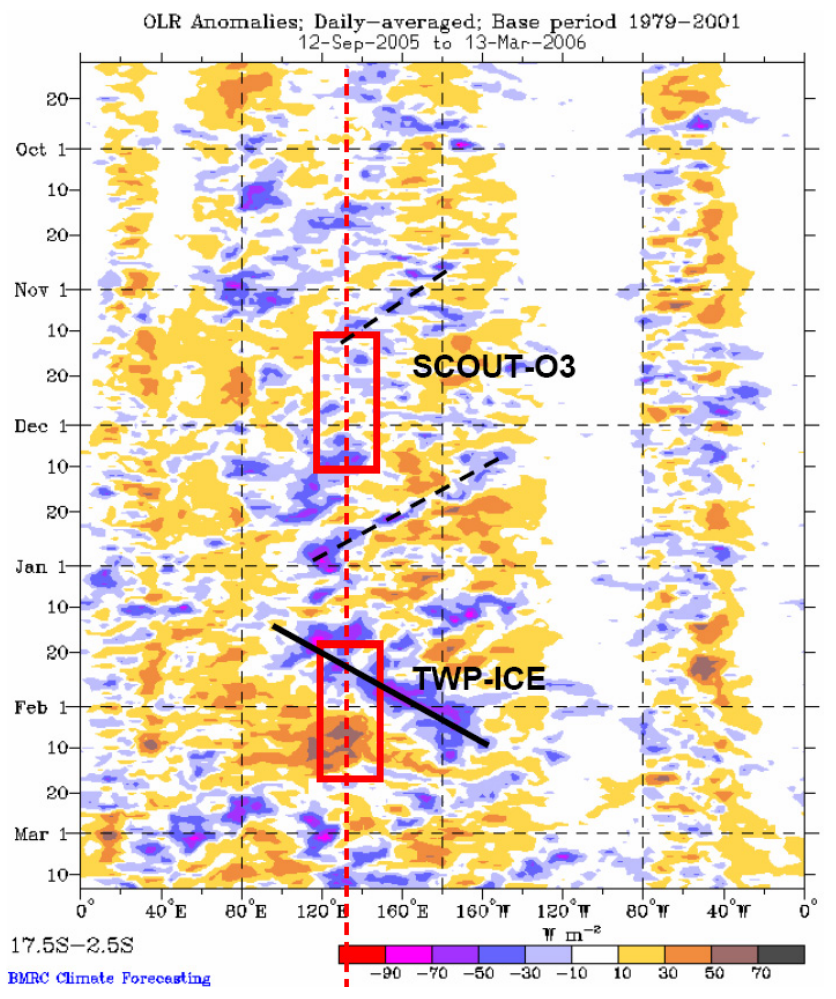

Fig. 4. Hovmöller diagram (longitude versus time from 12 September 2005 to 13 March 2006) of outgoing long-wave radiation (OLR) anomalies in the southern tropics $\left(17^{\circ} 30^{\prime} \mathrm{S}-2^{\circ} 30^{\prime} \mathrm{S}\right)$. Darwin is located at $12^{\circ} \mathrm{S} / 131^{\circ} \mathrm{E}$ denoted by the red dashed line. The time periods covered by the SCOUT-O3 and TWP-ICE campaigns are indicated by the red boxes. The ACTIVE campaign covered both periods and a few days before and after. The thick black line highlights the eastward propagation of convective activity indicative of the MJO. Black dashed lines indicate westward propagating equatorial waves. Source: Australian Bureau of Meteorology.

activity. A notable exception is a westward propagating wave reaching Darwin on about 10 November (black dashed line), indicative of a convectively coupled equatorial $n=1$ Rossby wave as described by Wheeler and Kiladis (1999). This interpretation is supported by an objective wave filtering analysis of OLR anomalies (Matthew Wheeler, personal communication; not shown). About half a dozen of similar events occurred during the six-month period represented by Fig. 4. The study of Wheeler and Kiladis (1999) indeed suggests that this type of waves makes a large contribution to OLR variability over Northern Australia in particular during southern hemisphere summer.

In contrast to Fig. 4, which does not show any eastward propagating anomalies during SCOUT-O3, the analysis of equatorial $\left(5^{\circ} \mathrm{S}-5^{\circ} \mathrm{N}\right)$ OLR anomalies presented by Shaik and Cleland (2006) suggests that there was a minor MJO event active in Australian longitudes at the commencement of the SCOUT-O3 campaign, during early November, and another was just commencing at the end of the campaign (early to mid-December). This may have contributed to the enhanced cloudiness (blue colors in figure) at Darwin during these periods. In between these events, during most of November, the western Indian Ocean $\left(80^{\circ} \mathrm{E}-120^{\circ} \mathrm{E}\right)$ experienced lower than normal convective activity while cloudiness at Darwin was still weakly above the 1979-2001 mean.

In contrast to SCOUT-O3, the TWP-ICE campaign was strongly influenced by an eastward propagating wave (black solid line) indicative of an active MJO (Shaik and Cleland, 2006). The monsoon onset occurred on 13 January, significantly later than the mean onset date of 28 December from the climatology. Quite typically, the onset coincided with the arrival of the MJO (Drosdowsky, 1996). In February, during the second half of the TWP-ICE campaign, there was a monsoon break with weather conditions more similar to the pre-monsoon situation encountered during SCOUT-O3.

In summary, the large-scale tropical circulation was close to its climatological mean during the SCOUT-O3 campaign and no major disturbance affected the area as diagnosed by OLR anomalies. The mean position of the Southern Hemisphere subtropical jet stream, on the other hand, was unusually close to the equator in November 2005 due to a series of Rossby wave breaking events affecting the weather at Darwin as described in the following section.

\section{Local conditions during campaign}

\subsection{Local profiles of wind and temperature}

Figure 5 presents the evolution of vertical profiles of wind and temperature at Darwin $\left(12^{\circ} 28^{\prime} \mathrm{S}, 130^{\circ} 51^{\prime} \mathrm{E}\right)$ from 10 November to 10 December 2005 as measured by radiosondes. Since Darwin radiosondes are assimilated into the ECMWF forecast system the corresponding profiles from the ECMWF model show almost exactly the same structures and are therefore not presented here. Fully equipped sondes are launched twice daily by the BoM at 23:00 and 11:00 UTC. Since Darwin local time is UTC $+9.5 \mathrm{~h}$, this corresponds to about 09:30 and 21:30 LT, respectively. Two additional sondes measuring only winds are launched daily at 05 and 17:00 UTC. The time periods covered by the eight local flights on 16, 19, 23, 25, 29, 30 (2x) November and 5 December, and by the transfer flights into (12 November) and out of Darwin (10 December), are emphasized by the black tick marks at the bottom of each panel.

Figure 5 documents the highly variable conditions during the campaign in terms of direction and speed of the flow in both the lower and upper troposphere. Vertical shear is of great importance for the evolution and structure of thunderstorms. In an environment with little shear the systems tend to be narrow and short lived. Mesoscale organization requires some degree of shear with bands of convection typically becoming aligned perpendicular to the low-level shear (surface to $700 \mathrm{hPa}$ ) (Keenan and Carbone, 1992). Large 

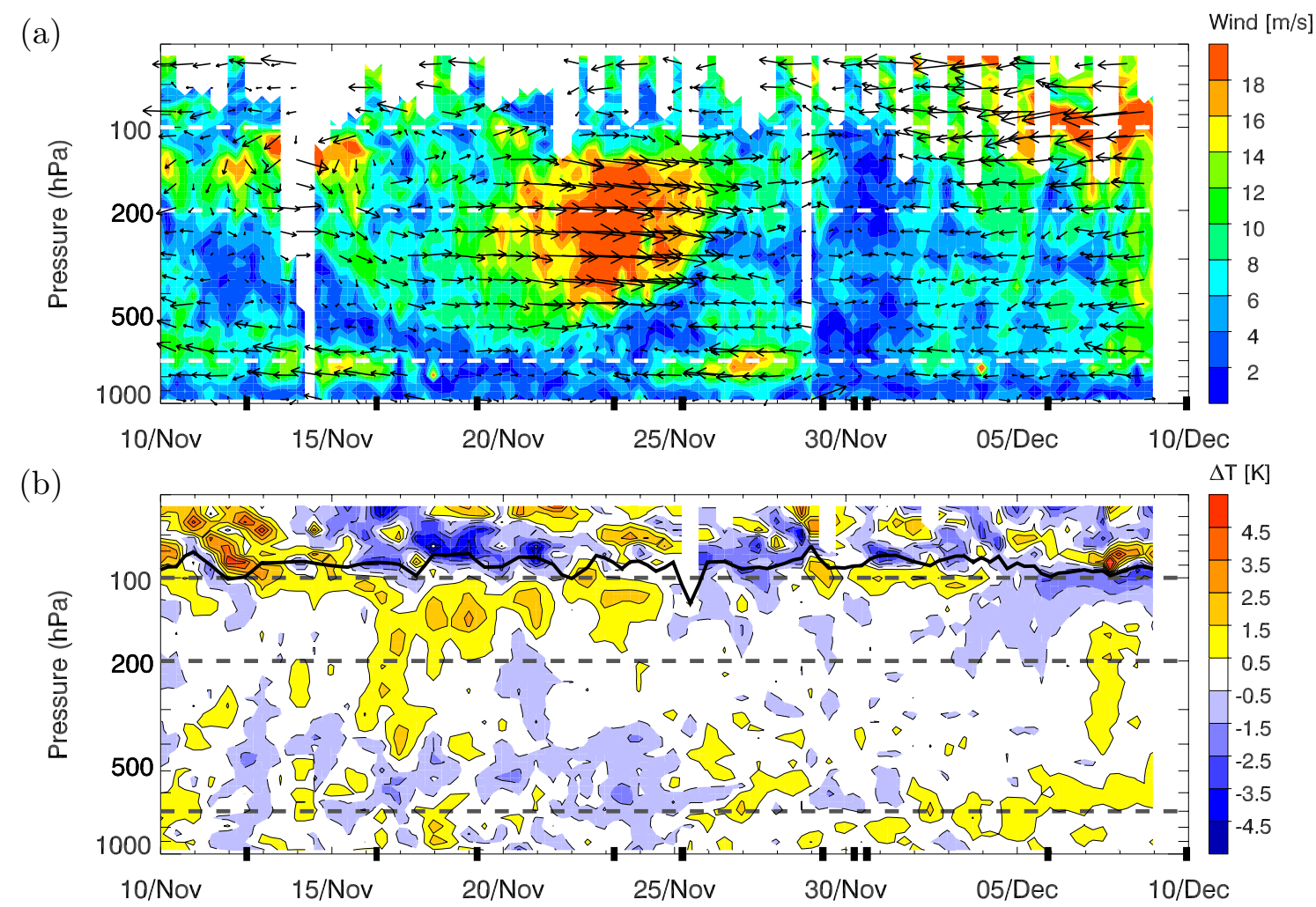

Fig. 5. Time evolution of vertical profiles from Darwin radiosonde observations (time given in UTC). (a) Horizontal wind speed (contours) and direction (arrows). An arrow pointing upwards thus indicates southerly winds. (b) Temperature anomalies $\left({ }^{\circ} \mathrm{C}\right)$ with respect to the 10 November-10 December diurnal mean cycle. For illustration, horizontal dashed lines are drawn at the steering level (700 hPa), main outflow $(200 \mathrm{hPa})$, and approximate tropopause level $(100 \mathrm{hPa})$. The black solid line in panel (b) denotes the cold-point tropopause. Black marks on the $\mathrm{x}$-axis indicate the times of the flight missions.

shear, on the other hand, can inhibit or delay thunderstorm development due to the growing convective plumes being torn apart by the shearing flow. Based on an analysis of radar and radiosonde data, May et al. (2009) found a negative trend in storm activity with increasing shear for storms over the Tiwi Islands. Since shear was correlated with wind speed itself, the time available for heating up the boundary layer air over the small islands becomes shorter with increasing shear. They suggest that this reduced time for boundary layer evolution, together with the rapid advection of storms off the islands under high shear conditions, explains this unexpected behavior.

The $700 \mathrm{hPa}$ level (lower dashed line in Fig. 5) is frequently referred to as the steering level which determines the mean motion of storm cells (Keenan and Carbone, 1992). Easterly winds dominated at $700 \mathrm{hPa}$ as expected for the premonsoon buildup (cf. Fig. 3). Accordingly, Hectors probed over the Tiwi Islands on 16, 25, and 30 November were moving from east to west. In contrast to this typical situation, weak westerlies prevailed between 19 and 23 November resembling monsoon conditions. Different from a real monsoon, however, the westerlies were only weak at the surface

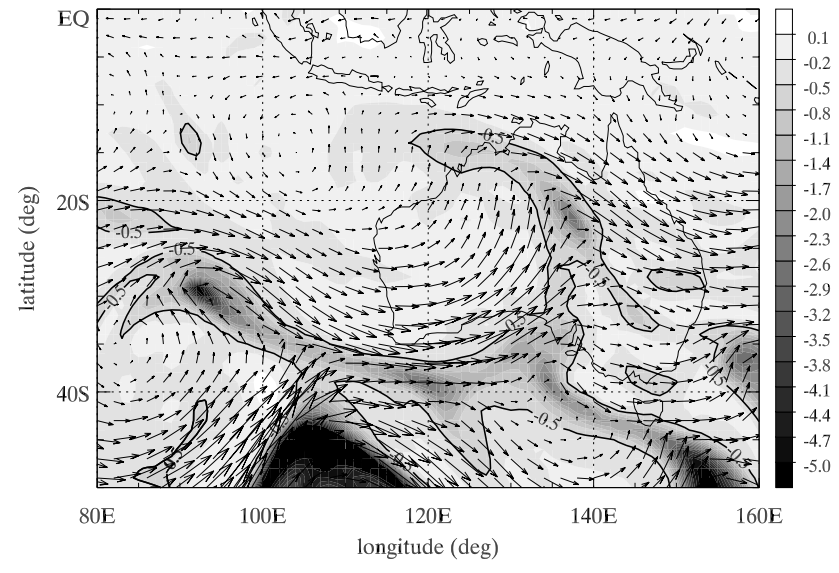

Fig. 6. Potential vorticity (pvu) and wind vectors at $300 \mathrm{hPa}$ on 23 November 18:00 UTC. Based on European Centre for Medium Range Weather Forecasts (ECMWF) analysis.

and the characteristic cross-equatorial monsoon flow at low levels and the pronounced easterlies at $100 \mathrm{hPa}$ (cf. Figs. 1d and 2d) were absent. 

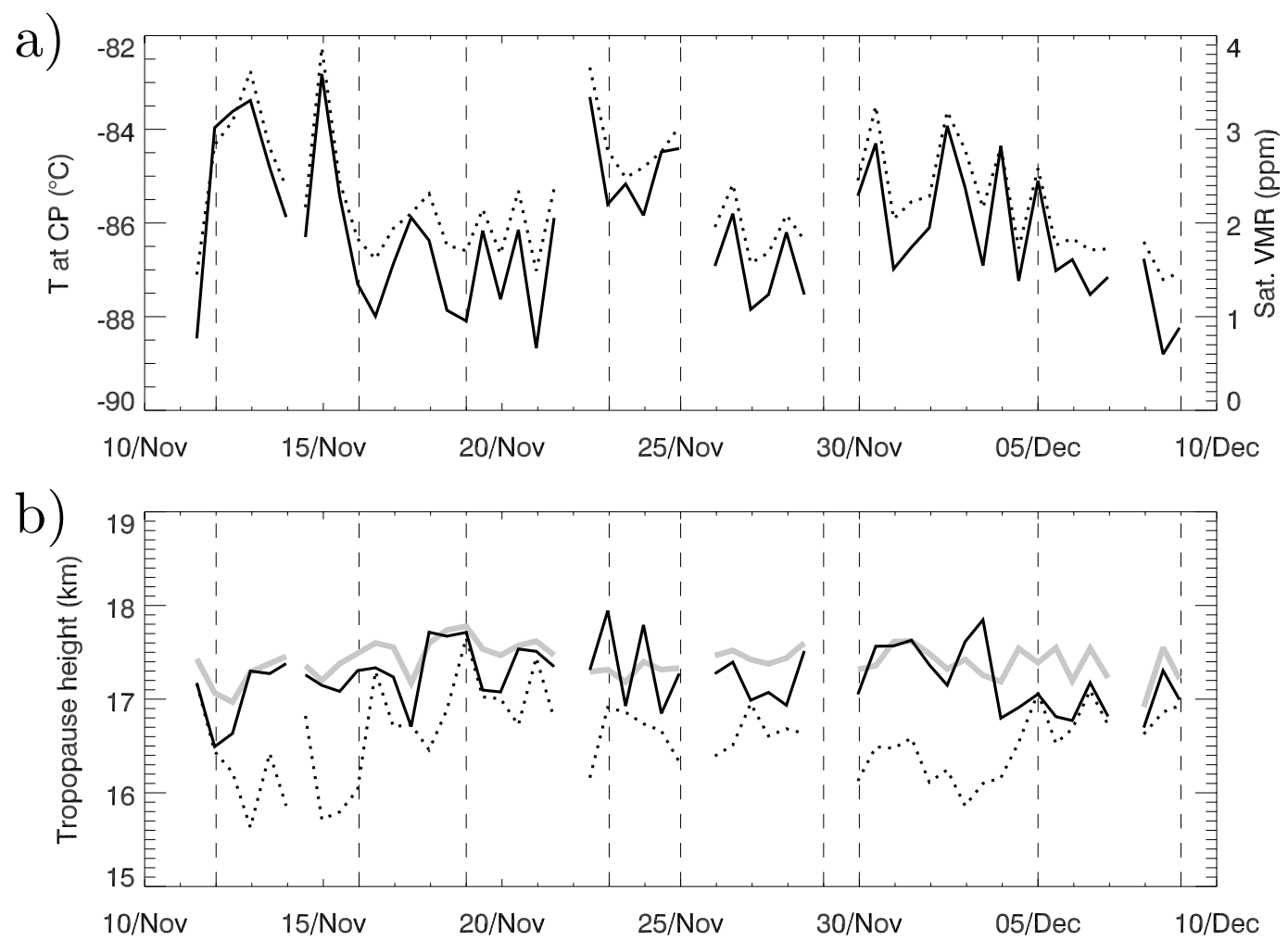

Fig. 7. Time evolution of tropopause parameters based on Darwin 00:00 UTC and 12:00 UTC radiosondes. (a) Temperature at the cold point tropopause (solid) and corresponding ice saturation volume mixing ratio (dotted). Flight days are marked by dashed vertical lines. (b) Geopotential height of the cold point tropopause (solid), the WMO lapse rate tropopause (dotted) and the $380 \mathrm{~K}$ potential temperature level (grey solid).

This unusual situation was related to the northward displacement of the subtropical jet, and was caused by a breaking Rossby wave approaching Darwin as shown in Fig. 6. The potential vorticity (PV) anomaly associated with the wave was stretched into a long filament which remained almost stationary for several days. On its leading edge the anomaly induced a strong mid-level westerly flow (see Figs. 5 and 6). The filament passed over Darwin around 25 November when PV reached a maximum absolute value of about $0.6 \mathrm{pvu}$ between 500 and $600 \mathrm{hPa}$, coinciding with the minimum in wind speed and change from westerly to easterly flow seen in Fig. 5. As shown by Allen et al. (2009), the intrusion of stratospheric air was clearly seen in vertical profiles from ozonesondes (launched by ACTIVE) and the Geophysica as dry, ozone-rich layers in the mid-troposphere on 23 and 25 November.

During the period of low level westerlies the lower troposphere was slightly colder than average by about $1^{\circ} \mathrm{C}$ (Fig. 5b) while relative humidity tended to be high near the surface (not shown), possibly due to the inflow of air from the nearby ocean waters west of Darwin. Convective activity was somewhat enhanced over the Arafura Sea north of Darwin (cf. Fig. 9b below) in the form of extended rain bands that frequently moved into Darwin from west to north-west. In the center of the intrusion south of Darwin, however, convection was suppressed, presumably due to large-scale descent as well as mixing in of dry air into developing cumuli as suggested by Allen et al. (2009).

$700 \mathrm{hPa}$ winds changed back to easterly on 24 November building up to a maximum speed of about $14 \mathrm{~m} / \mathrm{s}$ between 26 and 28 November. Such a jet-like maximum at $700 \mathrm{hPa}$ has also been observed in previous campaigns (Keenan and Carbone, 1992). Accordingly, the Hectors on 26 and 27 November as well as the one on 16 November all developed in a similar fashion with an average to late start, a rapid westward movement across the Tiwi Islands, and subsequent decay over the open water.

The $200 \mathrm{hPa}$ level ( $\sim 12.5 \mathrm{~km}$, central dashed line in Fig. 5) approximately corresponds to the mean altitude of storm outflow and thus determines the movement of the anvil as observed in infrared (IR) satellite imagery. As at $700 \mathrm{hPa}$, winds at $200 \mathrm{hPa}$ were highly variable during the campaign due to the proximity of the upper level ridge as explained in Sect. 2.1. Thunderstorm anvils were therefore blown out into completely different directions on different days. However, it should be noted that, in contrast to the Egrett and Falcon, the 
Geophysica flew mostly above the anvils, or near anvil tops, in order to sample convective overshoots. At these altitudes $(p<100 \mathrm{hPa})$ the winds were usually easterly and gaining in strength with increasing altitude due to the easterly QBO.

The temperature anomalies (Fig. 5b) reveal a wave-like pattern in the lower stratosphere inducing a warm phase at the tropopause from 10 to 14 November and a cold phase from 15 to 21 November. These anomalies are related to a large-amplitude equatorial Kelvin wave present during this period at the longitude of Darwin as shown by the analysis of Ern et al. (2008). The importance of this wave for dehydration will be discussed in a forthcoming paper.

The evolution of the conditions at the tropopause above Darwin (based on 00:00 UTC and 12:00 UTC radiosondes) is illustrated in Fig. 7. Mean $( \pm 1 \sigma)$ cold point and lapse rate tropopause temperatures were $-86.1 \pm 1.5^{\circ} \mathrm{C}$ and $-84.0 \pm 2.9^{\circ} \mathrm{C}$, respectively. Corresponding pressures were $89 \pm 6 \mathrm{hPa}$ and $101 \pm 8 \mathrm{hPa}$, and geopotential heights were $17240 \pm 350 \mathrm{~m}$ and $16580 \pm 430 \mathrm{~m}$, respectively. Ice saturation volume mixing ratios at the cold point tropopause varied between 1.4 and $3.9 \mathrm{ppm}$ with a mean ( \pm standard error of mean, $n=58$ ) of $2.30 \pm 0.09 \mathrm{ppm}$. The lowest value was observed on 21 November in connection with the cold phase of the Kelvin wave. The cold point tropopause usually coincided with a strong change in static stability but due to layers of enhanced stability, the lapse rate tropopause was frequently well below the cold point (Fig. 7b). The cold point tropopause was generally very close (within $300 \mathrm{~m}$ ) of the $380 \mathrm{~K}$ isentrope and on average $150 \mathrm{~m}$ lower.

These conditions are quite comparable to those encountered during the APE-THESEO campaign conducted over the equatorial Indian Ocean in February and March 1999 using the same aircraft (MacKenzie et al., 2006). Average cold point temperatures were about $1.5^{\circ} \mathrm{C}$ warmer during APETHESEO and more variable. The mean ice saturation VMR was correspondingly higher $(3.0 \pm 0.25 \mathrm{ppm})$ as compared to SCOUT-O3 (2.30 \pm 0.09 ppm).

The low temperatures encountered during SCOUT-O3 have proven to be invaluable for the compilation of climatologies of ice water content and $\mathrm{HNO}_{3}$ uptake in tropical, mid-latitude, and arctic cirrus recently performed by Schiller et al. (2008) and Krämer et al. (2008), respectively. The SCOUT-O3 $\mathrm{H}_{2} \mathrm{O}$ and $\mathrm{NO}_{\mathrm{y}}$ measurements allowed extending these climatologies to the very low temperature range.

\subsection{Convective activity}

The daily evolution of the 16:00 LT afternoon cloud field over the Top End between 16 November (first Hector flight) and 30 November (last Hector flight) is shown in Fig. 8 based on IR images of the Japanese geostationary satellite GMS. The red dot in each panel marks the position of Apsley Strait, which is a tidal channel separating the two Tiwi Islands Bathurst and Melville and a preferred location for storm initiation. Hector anvils are enclosed by white circles.
Their position relative to the red dot provides an indication for the direction of the outflow. These directions are largely consistent with the flow at $200 \mathrm{hPa}$ presented in Fig. 5a. Note that on 16 November there seems to be a southwest component rather than the expected southern one, but actually the system itself had moved rapidly to the west as mentioned in Sect. 3.1 whereas the outflow was due south. During the flights on 19, 23 and 25 November, convective outflow was directed to the east as expected. 26 and 27 November were again similar to 16 November with the systems themselves moving westward rather than the outflow. From 30 November to 2 December the outflow was almost stationary, again consistent with Fig. 5a.

During the period of low-level westerlies (19-23 November, and similarly 25 November) convection was enhanced over the Arafura sea but only moderate over the Top End. This contrasts with the period 29 November to 3 December which featured a more or less cloud-free ocean but intense continental convection over Northern Australia and the Tiwis. Two large oceanic mesoscale convective systems (MCS) moved into the investigation area on 20 and 22 November, and more shallow bands of rain passed the area on 21, 24 and 25 November. Rather weak Hectors externally forced by these disturbances developed on 20, 21, 22, 24 and 25 November whereas the Hector on 23 November was more isolated. The oceanic convection retreated to the north and west on 26 November leaving the Tiwi Islands free of clouds and giving way to a rather strong Hector. On 27 November, intense oceanic convection reappeared to the west over the Timor Sea. A strong Hector evolved similar to 26 November which, however, interacted with the oceanic disturbances at a later stage.

The broad cloudy area northeast of the Tiwis on 16 November is due to remainders of a huge mesoscale complex which had developed over Papua New Guinea one day earlier. It left behind a deck of cirrus clouds near the tropopause which should not be confused with the signatures of the locally active oceanic systems during the westerly wind period.

Figure 9 presents the time evolution of two indicators of convective activity, convective available potential energy (CAPE) and fractional cloud cover. CAPE is a frequently used measure for the intensity of convection to be expected on a given day. CAPE values (black line in Fig. 9a) are based on early morning (00:00 UTC) radiosondes representing tropospheric conditions around 09:00 LT before the start of convection. Although the maximum CAPE of all air parcels in the lowest $500 \mathrm{~m}$ was calculated, CAPE usually maximized for parcels very close to the surface, in agreement with the findings of McBride and Frank (1999). CAPE values derived from ECMWF model profiles are shown by the dotted line. The agreement with the sonde values is not particularly good $(r=0.67)$ probably due to CAPE being very sensitive to variations in low level moisture and temperature (McBride and Frank, 1999) and ECMWF data being representative for a 

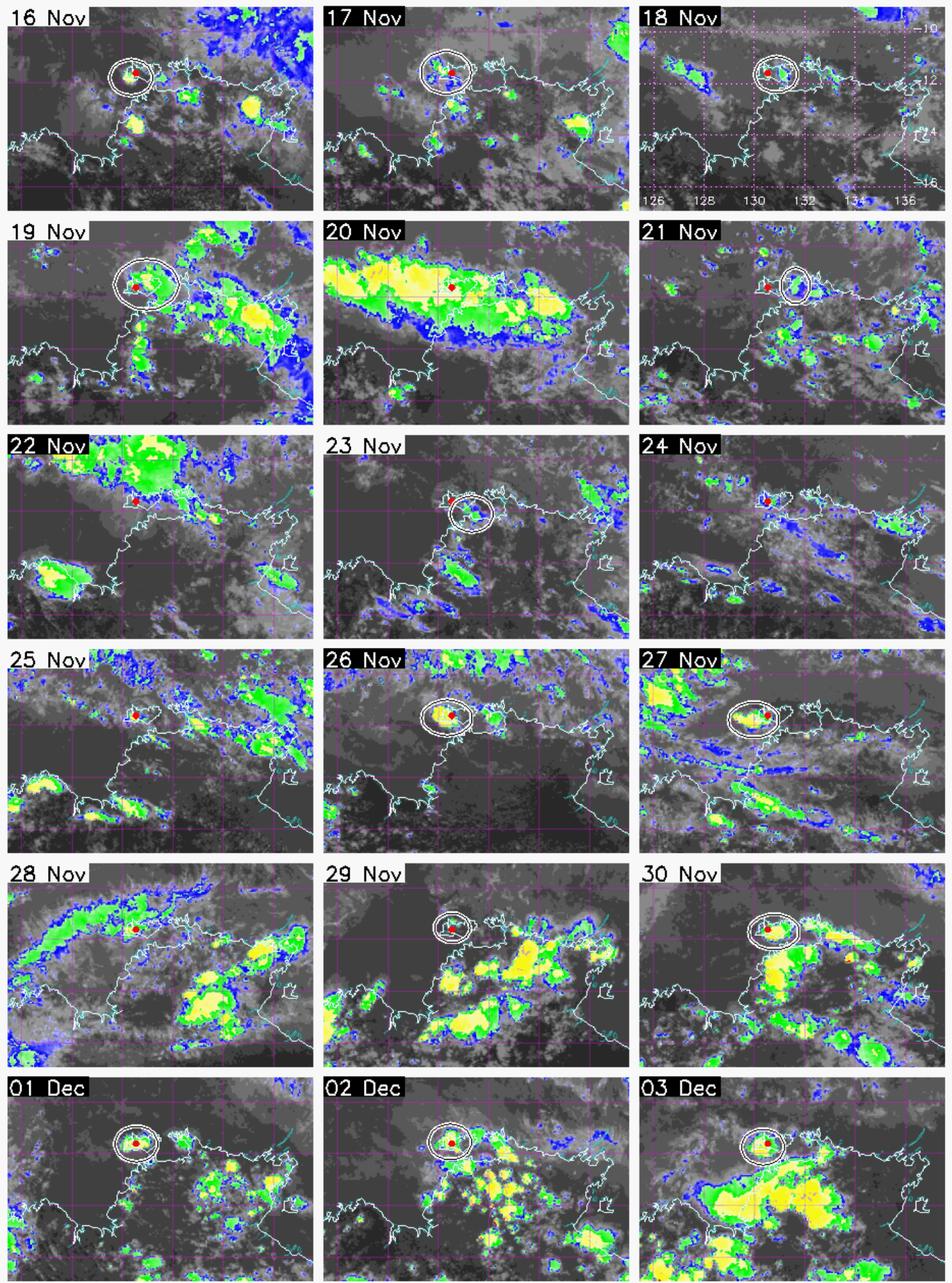

Fig. 8. Daily afternoon (06:30 UTC, 16:00 LT) GMS-5 satellite images (IR channel 4) over the Top End. Color scale is: $>250 \mathrm{~K}$ gray shades, 250-230 K blue shades, 230-210 K green shades, 210-190 K yellow shades, $<190 \mathrm{~K}$ red shades. The red dot marks the position of Apsley Strait separating the two Tiwi Islands. Days featuring a Hector can be identified by the white circle enclosing the anvil. Dates with black labels on white background are flight days. Latitude and longitude labels are shown for the top right panel only. 

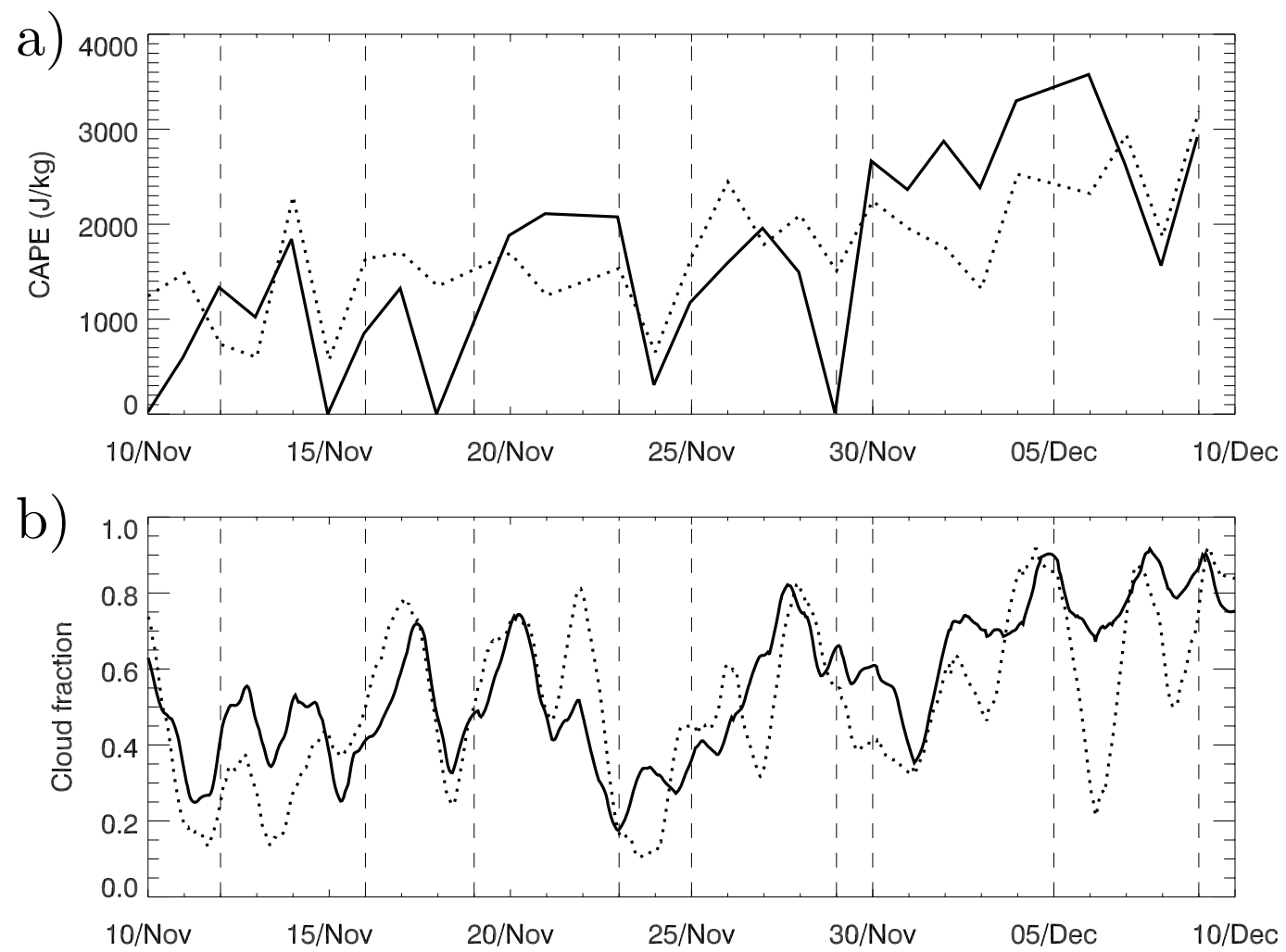

Fig. 9. Time evolution of indicators of convective activity. (a) CAPE derived from the 00:00 UTC radiosondes (solid) and from 00:00 UTC ECMWF profiles (dotted). (b) Fractional cloud cover over Top End $\left(129^{\circ} 30^{\prime}\right.$ to $134^{\circ} 30^{\prime} \mathrm{E}, 14^{\circ} 30^{\prime}$ to $\left.11^{\circ} \mathrm{S}\right)$ (solid) and over Arafura Sea $\left(129^{\circ} 30^{\prime}\right.$ to $134^{\circ} 30^{\prime} \mathrm{E}, 11$ to $\left.7^{\circ} 30^{\prime} \mathrm{S}\right)$ (dotted) derived from hourly GMS-5 IR satellite images and smoothed with a $24 \mathrm{~h}$ sliding average.

much larger area than the sondes (ECMWF data was used here at a resolution of $\left.1^{\circ} \times 1^{\circ}\right)$.

According to Keenan et al. (1990), Hectors typically develop in an environment of moderate CAPE around $2000 \mathrm{~J} / \mathrm{kg}$ consistent with our results. However, there was considerable day-to-day variability. On 10, 15, 18 and 29 November the measured CAPE was zero or near-zero. On these days there was either no Hector at all (15 November), only a weak one (18 November), or a very late Hector (10 and 29 November). Except for 29 November, these dips in CAPE are also reflected in reduced cloud cover as presented in Fig. $9 \mathrm{~b}$.

Both ECMWF and the soundings indicate the highest CAPE values between 30 November and 9 December well above $2000 \mathrm{~J} / \mathrm{kg}$. This period was convectively very active with strong Hectors developing on all days except for 4 and 5 December. On these days, reduced insolation in the morning due to widespread cirrus remaining from nighttime storms suppressed the convection over the Tiwis. High CAPE is thus no guarantee for a strong Hector but appears to be a prerequisite.

Similar to the findings of Keenan et al. (2000) there appears to be no strong association between CAPE and the mean flow. The period of low-level westerlies, for example, does not stand out in a notable way in terms of CAPE. On most days where flights were dedicated to study Hector (19, 25, 30 November) CAPE values were well above $1000 \mathrm{~J} / \mathrm{kg}$. CAPE was comparatively low on 16 November consistent with a moderate activity over the Tiwis and the Top End as seen in Fig. 8. The highest CAPE of about $2600 \mathrm{~J} / \mathrm{kg}$ was present on the 30 November flight which indeed turned out to be the "golden Hector day" of the campaign.

\section{Individual flight summaries}

An overview of the local flights of the M55 Geophysica (hereafter referred to as M55) and the Falcon conducted in Darwin including statements on main scientific targets and meteorological situation are presented in Tables 1 and 2 separately for flights dedicated to Hector and for survey/transfer flights.

The M55 is a Russian high altitude aircraft with a ceiling altitude of about $21 \mathrm{~km}$ (Stefanutti et al., 1999). It was equipped with a comprehensive in-situ chemistry and microphysics package, the downward pointing miniature aerosol Lidar MAL, and the microwave temperature profiler MTP (Gary, 2006). The M55 was primarily used to probe anvil tops and overshoots and the structure of the tropopause 
Table 1. Overview of flights dedicated to Hector.

\begin{tabular}{|c|c|c|c|c|c|}
\hline F\# & Date & $700 \mathrm{hPa}$ steering & $200 \mathrm{hPa}$ outflow & Scientific goals & Remarks \\
\hline F1 & Wed, 16 Nov & $\mathrm{E} \rightarrow \mathrm{W}$ & $\mathrm{N} \rightarrow \mathrm{S}$ & $\begin{array}{l}\text { Hector, upwind survey, } \\
\text { anvil, joint mission with } \\
\text { ACTIVE }\end{array}$ & $\begin{array}{l}\text { Weak, isolated Hector, late stage probed over } \\
\text { ocean. Large systems south of Darwin. Cloud } \\
\text { deck to NE from a huge MCS near Papua New } \\
\text { Guinea. }\end{array}$ \\
\hline $\mathrm{F} 2$ & Sat, 19 Nov & $\mathrm{W} \rightarrow \mathrm{E}$ & $\mathrm{SW} \rightarrow \mathrm{NE}$ & Cirrus, Hector & $\begin{array}{l}\text { Reasonable Hector, early development, multiple } \\
\text { cells. Many other systems over Top End along sea } \\
\text { breeze front. }\end{array}$ \\
\hline $\mathrm{F} 4$ & Fri, 25 Nov & $\mathrm{E} \rightarrow \mathrm{W}$ & $\mathrm{NW} \rightarrow \mathrm{SE}$ & Cirrus, late Hector & $\begin{array}{l}\text { Weak Hector, late development. Rain bands over } \\
\text { ocean, monsoon-like conditions. }\end{array}$ \\
\hline F5 & Mon, $28 \mathrm{Nov}$ & - & - & Hector, MCS & $\begin{array}{l}\text { Geophysica flight aborted, Falcon sampled out- } \\
\text { flow of Hector }\end{array}$ \\
\hline F7 & Wed, 30 Nov & $\mathrm{E} \rightarrow \mathrm{W}$ (weak) & $\mathrm{E} \rightarrow \mathrm{W}$ & $\begin{array}{l}\text { Hector, joint mission with } \\
\text { ACTIVE }\end{array}$ & $\begin{array}{l}\text { Beautiful Hector, almost stationary anvil. Many } \\
\text { large systems over Top End. }\end{array}$ \\
\hline F8 & Wed, 30 Nov & $\mathrm{E} \rightarrow \mathrm{W}$ (weak) & $\mathrm{E} \rightarrow \mathrm{W}$ & post Hector, cirrus & \\
\hline
\end{tabular}

Table 2. Overview of local survey and transfer flights.

\begin{tabular}{|c|c|c|c|}
\hline F\# & Date & Scientific goals & Remarks \\
\hline T6 & Sat, 12 Nov & Transfer flight & Brunei $\rightarrow$ Darwin \\
\hline F3 & Wed, 23 Nov & TTL survey & $\begin{array}{l}\text { Survey flight towards equator. Detailed prob- } \\
\text { ing of rather quiescent TTL. Large monsoonal } \\
\text { activity north of flight path. }\end{array}$ \\
\hline F6 & Tue, 29 Nov & Mesoscale convective system & $\begin{array}{l}\text { Detailed probing of TTL along NS legs with } \\
\text { profiles at northern and southern ends. Sev- } \\
\text { eral large MCS over Top End passed at different } \\
\text { stages of the flight. }\end{array}$ \\
\hline F9 & Mon, 5 Dec & Envisat validation. & \\
\hline $\mathrm{T} 7$ & Sat, $10 \mathrm{Dec}$ & Transfer flight & Darwin $\rightarrow$ Brunei \\
\hline
\end{tabular}

region. An important goal of the Hector missions was to study the role of convective overshoots in hydrating (Kley et al., 1982; Corti et al., 2008) or dehydrating (Danielsen, 1982; Sherwood and Dessler, 2001) the tropopause region and lower stratosphere. For the 12 transfer flights from Europe to Darwin and back and for one local flight, some instruments were replaced by remote sensors including the thermal IR instruments MIPAS-STR (Höpfner et al., 2007) and CRISTA-NF (Spang et al., 2007), and the microwave instrument MARSCHALS. Water vapor profiles measured by CRISTA-NF along selected transfer flights were presented by Hoffmann et al. (2008).

The German DLR Falcon was equipped with an aerosol/water vapor differential absorption Lidar (DIAL) and several in-situ instruments. It was used to probe the vertical structure of the cloud and humidity field, to guide the Geophysica, and to characterize the anvils in-situ at their main outflow altitude of about $200 \mathrm{hPa}$. A more detailed overview of the instrument payloads was given by Vaughan et al. (2008).

On the transfer flights down to Darwin, a third aircraft joined in, a Swiss learjet carrying the microwave radiometer
AMSOS (Vasic et al., 2005; Müller et al., 2008) to measure water vapor profiles from the upper troposphere to the mesosphere. This aircraft returned before the start of the local campaign.

\subsection{November, first Hector flight}

This mission was conducted jointly with ACTIVE and involved flights of four different aircraft to sample the inflow into the storm (Dornier), the anvil (Falcon and Egrett) and the above anvil environment and convective overshoots (M55). Only a weak and late Hector developed on this day of which two stages are shown in the satellite (top) and radar (bottom) images in Fig. 10, with the flight paths of the M55 (top) and Falcon (bottom) overlaid. The two aircraft first headed north crossing Melville Island which was still quiet at this time (label 1 in figure). The M55 then flew a holding pattern upstream of the Tiwis perpendicular to the flow in order to characterize the background air between 14 and $19 \mathrm{~km}$ altitude into which the anvil would evolve (label 2 in panel a). The Falcon flew a similar pattern but further north to probe with its Lidar the high level cirrus associated with the massive mesoscale system above Papua New Guinea mentioned 

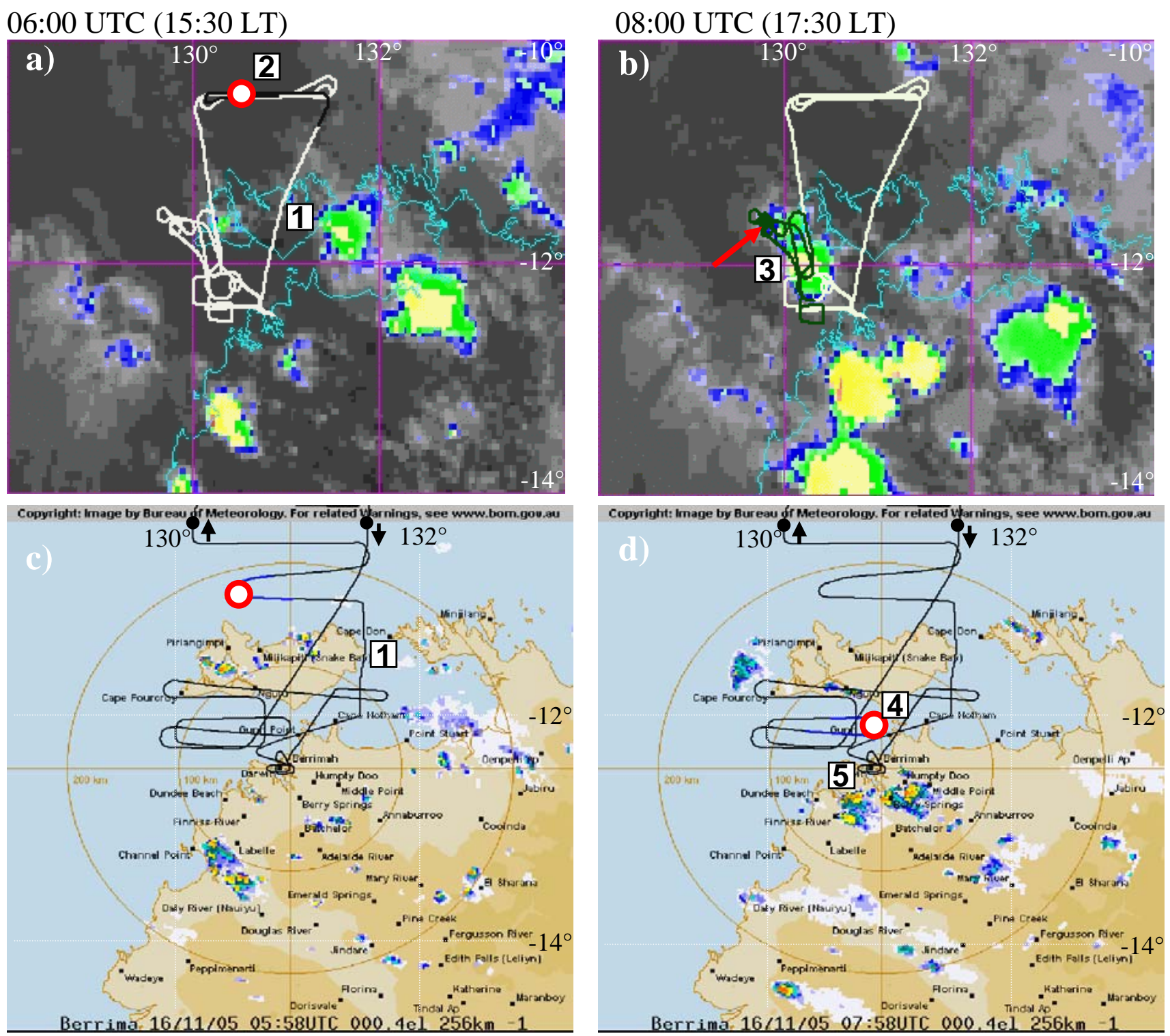

Fig. 10. GMS-5 IR channel 4 (top) and Berrima $256 \mathrm{~km}$ range radar pictures (bottom) of 16 November 15:30 LT (left) and 17:30 LT (right), respectively. For satellite image color scale refer to Fig. 8. Radar images show rain rates changing from light (blue) to moderate (yellow) to heavy (red). Flight paths of Geophysica (top) and Falcon (lower panels) are overlaid. Positions where the Falcon leaves the domain of the Radar image are marked in the lower panels. Aircraft positions corresponding to the time of the corresponding satellite or radar image are highlighted by circles (or by a red arrow in panel b). Specific points of interest referred to in the discussion are marked by black numbers in white squares.

earlier (cf. Fig. 8). With strong easterly steering (Fig. 5a), a single-cell Hector blew up over Bathurst Island near Apsley Strait around 15:10 LT (Fig. 10, left panels). Radar echoes reached up to a maximum altitude of about $17 \mathrm{~km}$ around 16:30 LT. The M55 approached the cell from the north descending stepwise from $19 \mathrm{~km}$ down to the anvil top. By the time the M55 arrived, the anvil was already detached and moving south (Fig. 10b, label 3). As the main activity had been advected off the coast over the Timor Sea by 17:30 LT, the M55 headed back northwest trying to sample the overshoots of a mildly active and already dying cell (Fig. 10b, red arrow). It finally returned to continue probing the environment above the main anvil by slowly descending into the top of the cloud (label 3 again).

After characterizing the inflow region in the north the Falcon returned to the south of the Tiwis where it was flying east-west cross-sections at $12600 \mathrm{~m}$ below the anvil thereby characterizing its vertical structure by Lidar (Fig. 10d, 
label 4). The Egrett flew northeast-southwest oriented transects above the Falcon and inside the anvil at 13100 and $13700 \mathrm{~m}$, whereas the Dornier was characterizing the low level inflow by flying large circles around Bathurst and the active cells. The final return of the four aircraft to Darwin was complicated by a number of highly active cells popping up along the sea breeze front south and east of Darwin (Fig. 10d, label 5) but they all managed to land safely as the systems stayed south of the airport.

\subsection{November, second Hector flight}

With weak westerly steering of 3-5 m/s (see Fig. 5a) the first cells developed over the eastern end of Melville Island on the opposite side of the Tiwis compared to 16 November. On both days the convection was thus initiated along the sea breeze front opposing the main flow, which is typical for the evolution of Island convection (Keenan et al., 2000). More cells soon followed along the northwest coast of Melville and south coast of Bathurst. These cells were all short-lived consistent with the low vertical shear (Fig. 5a). By the time the Falcon and M55 took off, multiple cells had formed over Melville Island concentrating along the southern sea breeze front in an east-west oriented line parallel to the steering flow (Fig. 11c). Note that the shape of the Tiwis favors the formation of zonally oriented sea breeze fronts at the northern and southern coastlines (e.g. Carbone et al., 2000). Cold pool formation by these early storms probably led to mesoscale organization and a reorientation of the system (see Carbone et al. (2000) for a general description of this process) with multiple cells now lining up perpendicular to the steering flow as nicely seen one hour later in Fig. 11d. By this time the cells were already decaying and the M55 was flying at $18.5 \mathrm{~km}(410-430 \mathrm{~K}$ potential temperature) above the mature anvil (Fig. 11b, label 1). According to the pilot's report no active overshoots were visible anymore but only a diffuse haze up to $18.5 \mathrm{~km}$. Significant gravity wave activity was experienced by the pilot who reported that the vertical speed indicator showed ascent at $5 \mathrm{~m} / \mathrm{s}$.

In addition to sampling Hector, the Falcon and M55 flew long north-south transects (label 2) as the trajectory forecasts indicated largely different air mass origins north and south of Darwin (see trajectory analysis presented in Sect. 5). On the returning transect at about 06:45 UTC the M55 revisited the aged Hector anvil porpoising at the top of the cirrus deck (label 3). The Falcon was following the same north-south transect thereby passing the Hector anvil downstream (to the east) of the Tiwis four times between 04:45 and 06:30 UTC at different stages of ageing (label 4). The Falcon Lidar measurements indicate a mean anvil top of approximately $17.5 \mathrm{~km}$. Significant development of convection started over the Top End along the sea breeze front around 05:00 UTC (Fig. 11d). Clouds associated with these systems were probably crossed during the final descent into Darwin airport.

\subsection{November, third Hector flight}

This flight was conducted during the period influenced by the breaking Rossby wave and was only partly dedicated to Hector since the Tiwis were still influenced by the frequent passage of oceanic systems. If no Hector were to develop soon after take-off, the M55 would join the Falcon in probing cirrus clouds over the Timor Sea where the ice-cloud forecast of the University of Lancaster predicted the presence of high altitude cirrus formed in-situ (see Ren et al., 2007 for the cirrus forecast methodology).

The M55 first flew a holding pattern north of the Tiwis where it characterized the tropopause region in east-west direction at two flight levels slightly below $(\sim 370 \mathrm{~K})$ and above $(\sim 390 \mathrm{~K})$ the cold point tropopause, respectively (Fig. 12a, label 1). The Falcon made a transect along the same line but in opposite direction (Fig. 12c, label 1). As there was little sign of convective growth over the Tiwis by 13:30 LT, the Falcon and M55 were sent onto a long north-eastward leg to point $127^{\circ} \mathrm{E}$ and $9^{\circ} 30^{\prime} \mathrm{S}$ at the border of the Brisbane Flight Information Region (label 2). At that point the Falcon made a right turn towards a large cloud system in the north visible in Fig. 12b whereas the M55 made a left turn. Both airplanes then flew north-south transects back and forth along $129^{\circ} \mathrm{E}$ to connect the cloudy and clear parts of the domain, still focussing on observations of cirrus clouds (Fig. 12b, label 3). Short-lived cells popped up over the Tiwis around 14:30 LT but sustained activity only started after 15:00 LT over north-western Melville and Bathurst Island. The eastern parts of the Tiwis remained quiet most probably due to the presence of high level cirrus reducing the solar heating over that part of the Island. Finally, all convection concentrated onto a single Hector cell near Apsley Strait which was active for only a short time from 15:18 to 15:58 LT (see Fig. 12d). Despite the expected distinct easterly steering this cell was surprisingly stationary. The M55 was immediately directed to Hector when it appeared in the radar images but upon arrival around 16:20 LT the cell was already dying. Nevertheless, the M55 was able to probe extensively the air above a thick and completely flat anvil (with a top at about $17 \mathrm{~km}$ ) in a primrose-like pattern, each loop flown at a lower altitude (Fig. 12b, red arrow). On its return to Darwin, the Falcon passed Hector downstream to the east (Fig. 12d, label 4) remotely sensing the vertical structure of the anvil by Lidar. Landing was again complicated by a squall line moving west towards Darwin airport (Fig. 12b, d). The Falcon landed before and the M55 immediately after passage of this system.

\subsection{November, "golden Hector day"}

This mission was again conducted jointly with ACTIVE. Hector was much taller and stronger than in the previous examples. Convection was initiated around 13:00 LT. In contrast to 16 and 19 November, it was triggered on the upstream rather than on the downstream (in terms of the steering wind) 


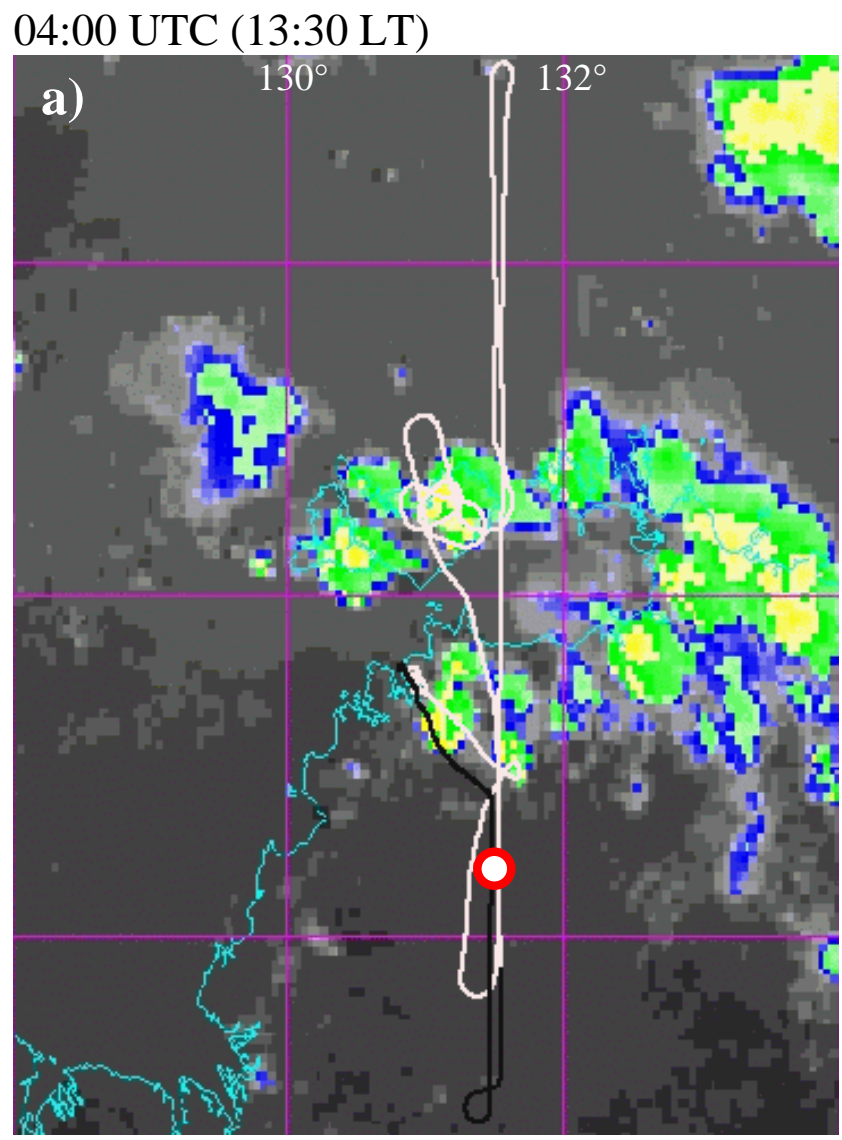

Copyright: Image by Bureau of Meteorology. For related Warnings, see www.bom.gov.au

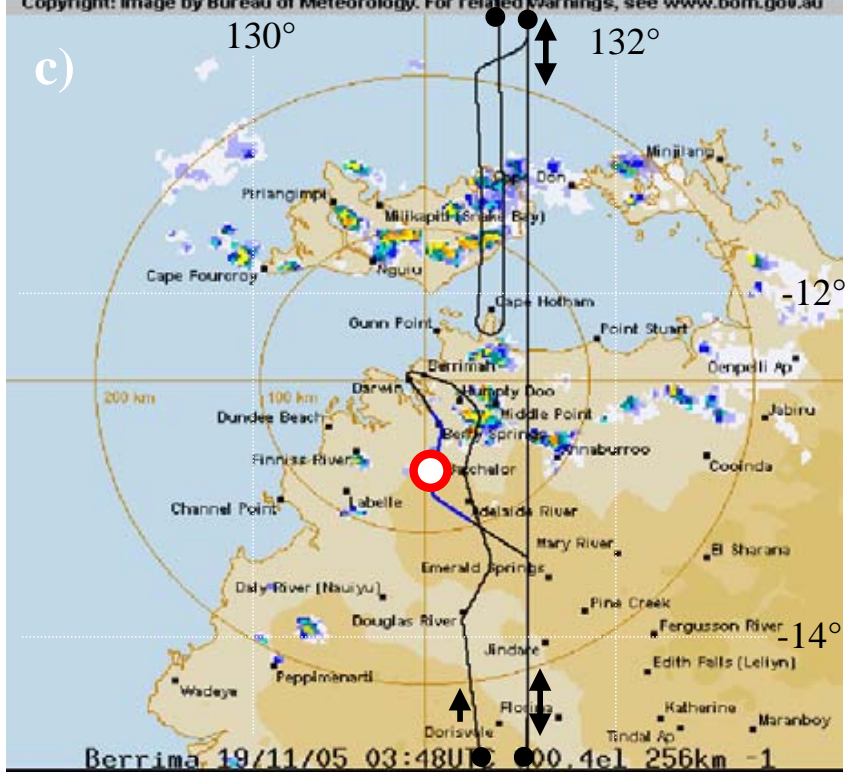

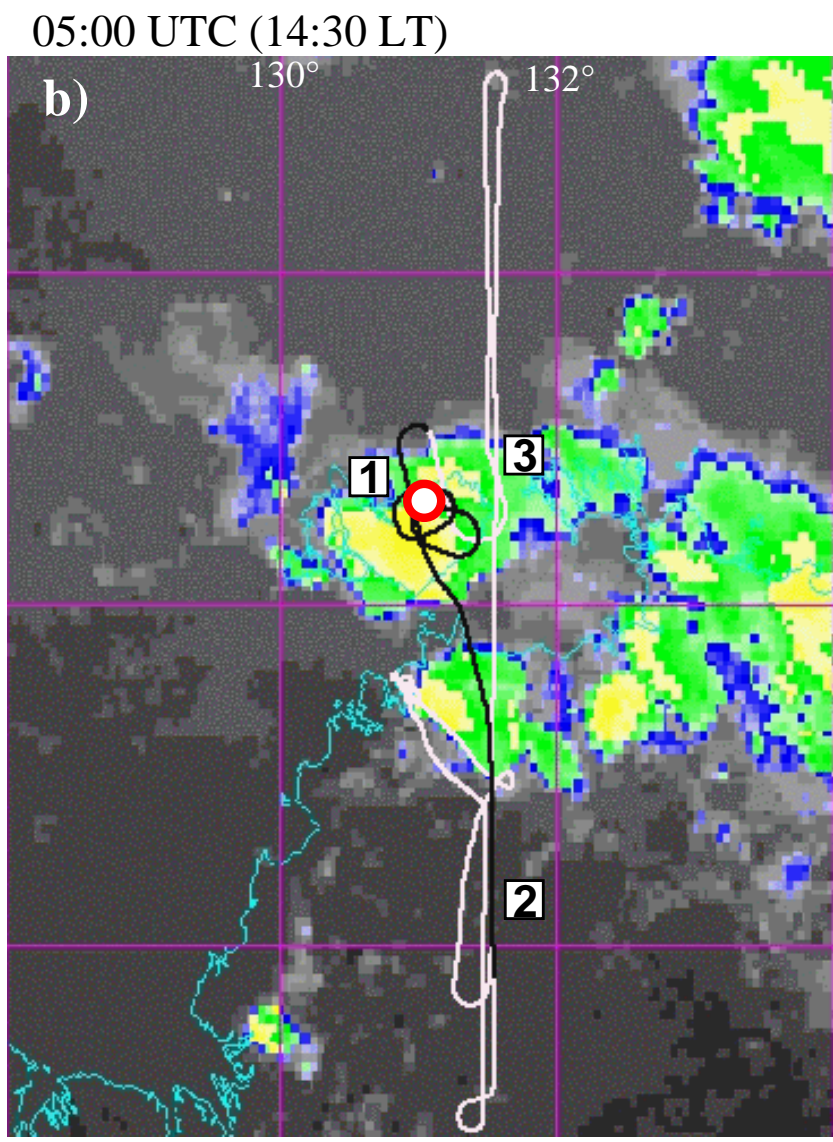

Copyright: Image by Bur eau of Meteorology. For related/Marnings, see www.bom.gov.au

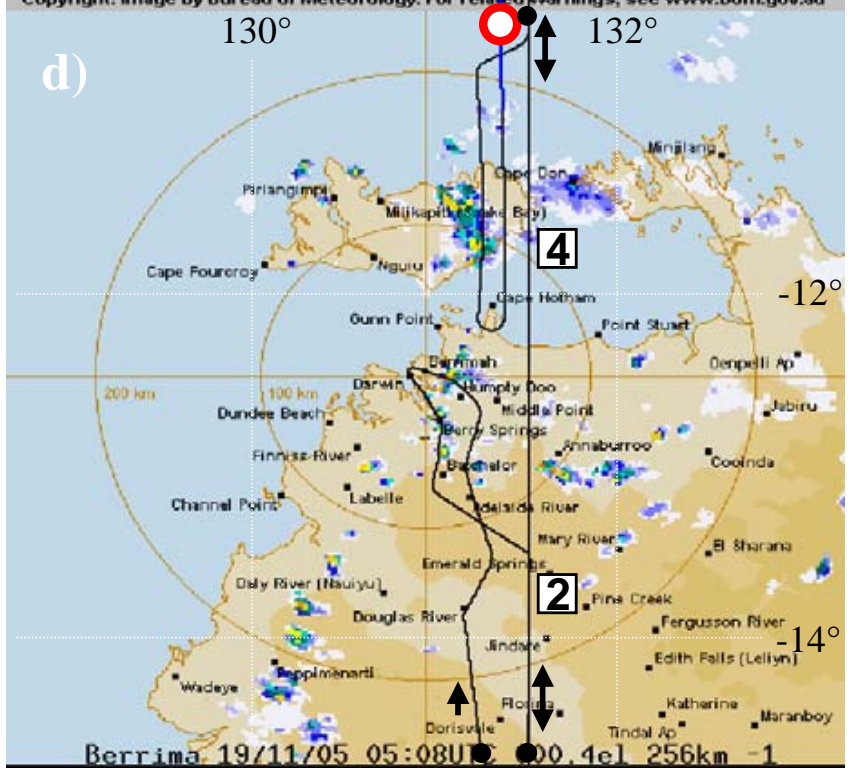

Fig. 11. GMS-5 IR channel 4 (top) and Berrima $256 \mathrm{~km}$ range radar pictures (bottom) of 19 November at 13:30 LT (left) and 14:30 LT (right), respectively. 
04:00 UTC (13:30 LT)

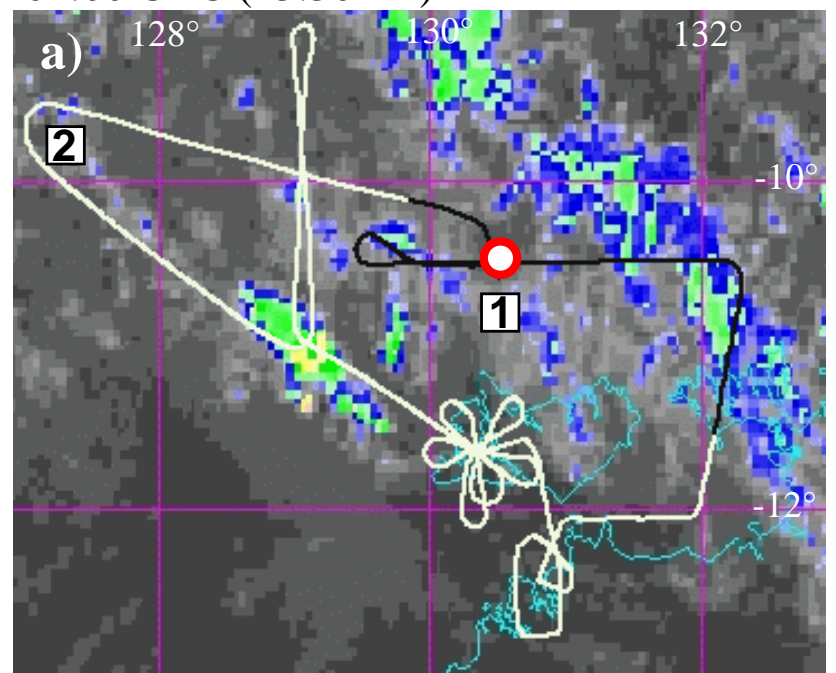

04 UTC (1330 LT)

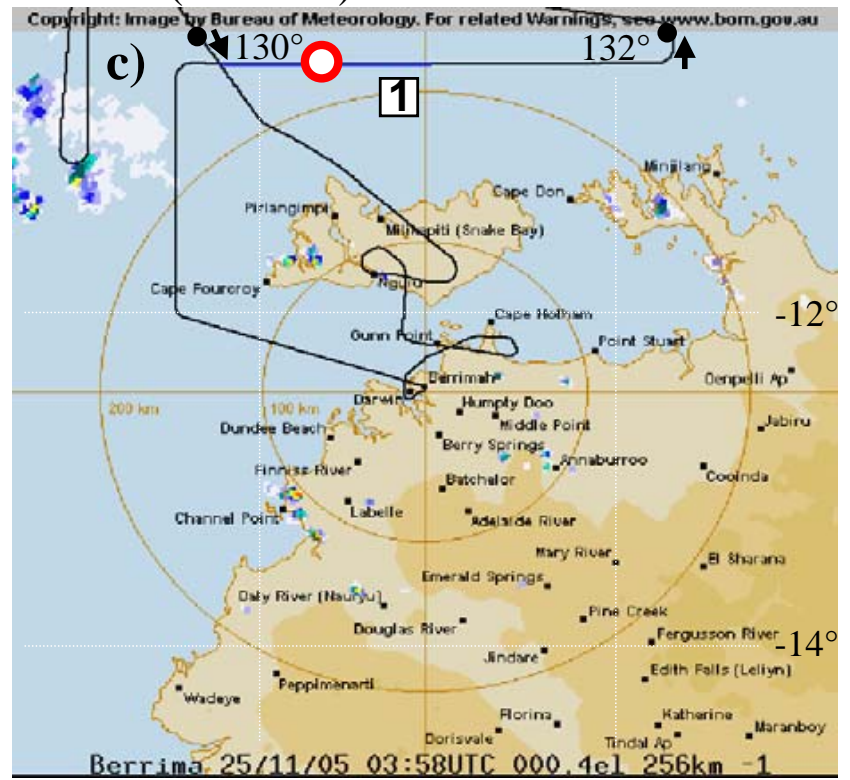

07:00 UTC (16:30 LT)

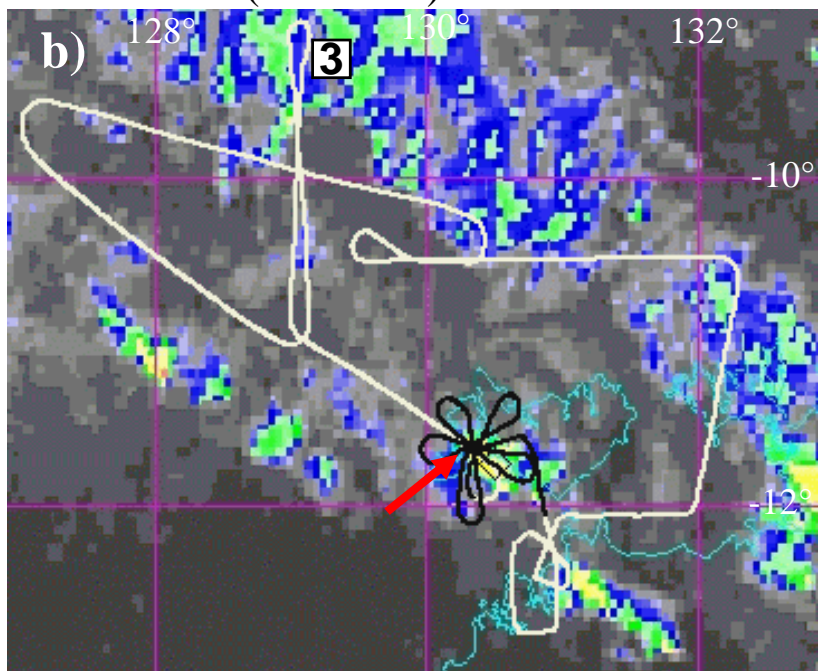

06 UTC (1530 LT)

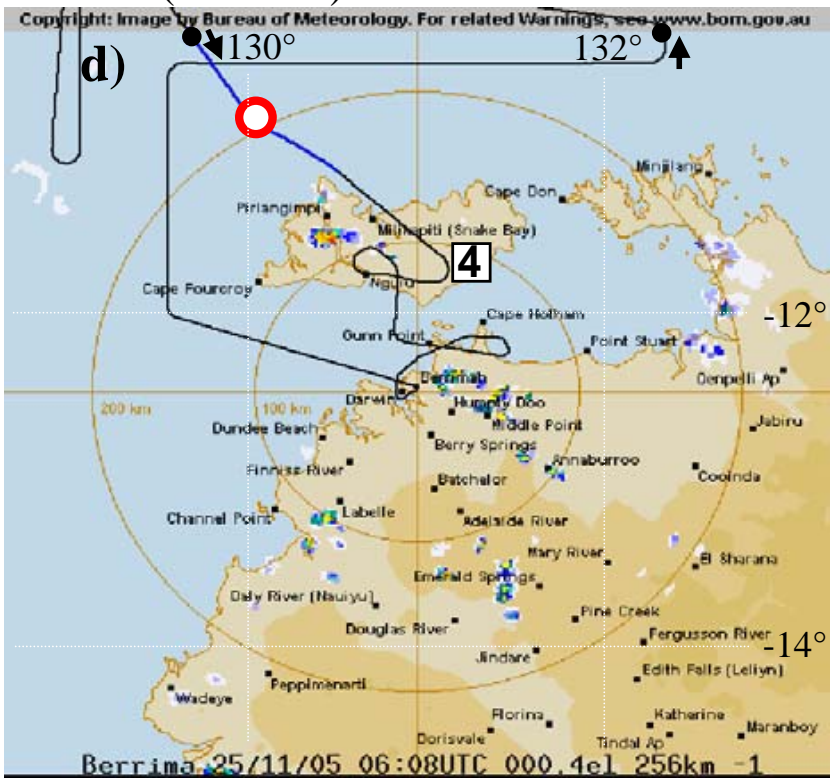

Fig. 12. GMS-5 IR channel 4 (top) and Berrima $256 \mathrm{~km}$ range radar pictures (bottom) of 25 November 13:30 LT (left) and 17:30 LT (top right) and 16:30 LT (bottom right), respectively.

sea breeze front over east Melville Island. However, the steering was generally weak on this day. Deep convection then rapidly developed all over Melville Island, arranging itself into a squall line propagating southward (Fig. 13c). Very light upper-level winds (Fig. 5a) caused the anvil to flow radially out from the storm complex with a slight north-eastward drift.

The Falcon and M55 first flew an east-west transect south of the Tiwis to characterize the upstream environment (label 1), though "upstream" was not well defined on this day. The Falcon then characterized the region north of the Tiwis (label 2) occasionally approaching the edge of the Hector anvil (e.g. around 16:30 LT). Both north and south of the
Tiwis cirrus was ubiquitous between 14 and $17.5 \mathrm{~km}$ mostly unrelated to Hector. Near Hector the cirrus deck usually became too thick for the Lidar to penetrate so the morphology of the anvil is difficult to determine in these cases. Around 17:10 LT, before returning to Darwin, the Falcon made a last approach of Hector at its southern edge recording cirrus up to about $18.2 \mathrm{~km}$ well above the levels of the background cirrus.

As seen in Fig. 13a, b the M55 spent most of its time above Hector. The downward pointing Lidar MAL onboard the M55 shows a mean anvil deck at $17 \mathrm{~km}$ and overshoots reaching up to about $18 \mathrm{~km}$. Individual cirrus apparently detached from the anvil were recorded even up to the flight level at $18.5 \mathrm{~km}$ well inside the stratosphere, consistent with 

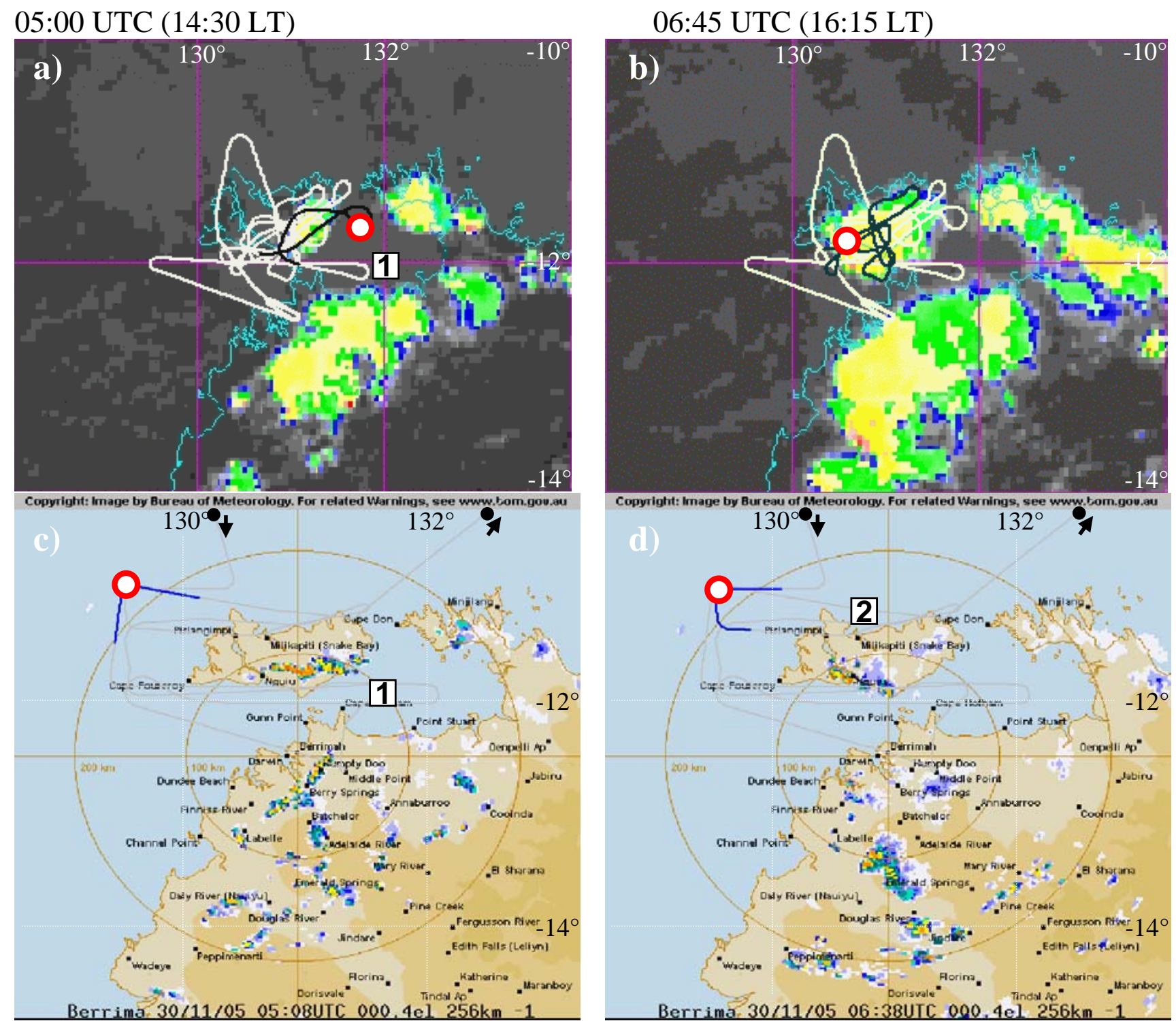

Fig. 13. GMS-5 IR channel 4 (top) and Berrima $256 \mathrm{~km}$ range radar pictures (bottom) of 30 November 15:30 LT (left) and 17:30 LT (right), respectively.

the Falcon observations and confirmed by the in-situ instruments. The effect of this event on hydrating the lower stratosphere is described in detail by Corti et al. (2008). According to Schiller et al. (2008), the ice water content observed during such Hector events penetrating the tropopause was higher by several orders of magnitude compared to that of other cirrus typically formed at the cold tropical tropopause. The detailed analysis of ice particle size distributions presented by de Reus et al. (2008) demonstrates that ice crystals observed in Hector overshoots above the tropopause comprised sizes as large as $400 \mu \mathrm{m}$ maximum dimension and an ice water content of $0.1 \times 10^{-3}$ to $1.7 \times 10^{-3} \mathrm{~g} / \mathrm{m}^{3}$.
The Dornier again flew circles around the Tiwi Islands, measuring profiles between $550 \mathrm{~m}$ and $3200 \mathrm{~m}$. With such an extensive anvil, the Egrett could only sample one part of it in detail and concentrated on the radial flow over NE Melville Island.

Apart from featuring a strong Hector, this day was a true "golden day" as the meteorological conditions were favorable for a second flight mission targeted at aged anvil outflow. On the evening of 30 November, less than 4 hours after landing, the Falcon and M55 took off again to re-sample the air masses lofted by Hector and to find indications of hydration or dehydration after evaporation and sedimentation of ice particles. Since tropopause-level winds were light, 


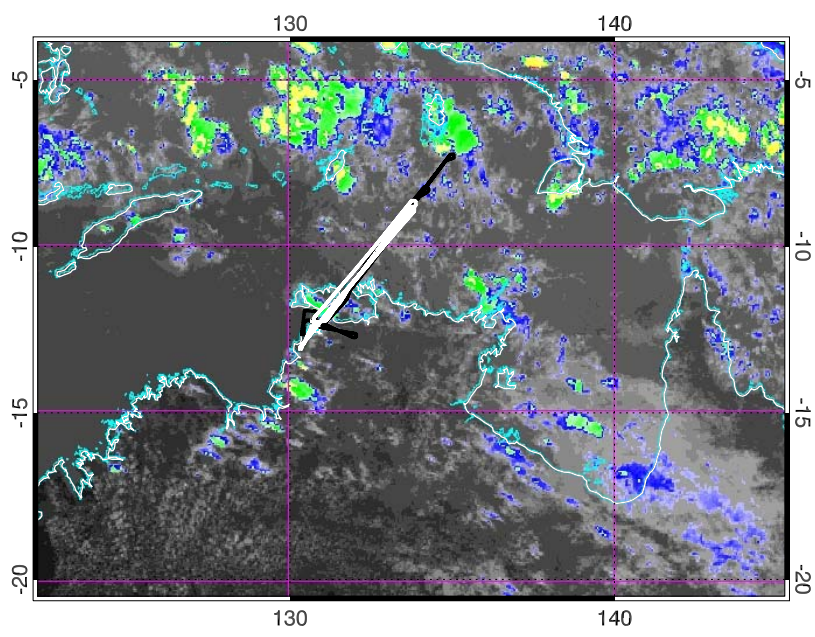

Fig. 14. GMS-5 IR image of 23 November valid at about 06:00 UTC (05:30 LT) with flight paths of the M55 Geophysica (white) and Falcon (black) overlaid.

the aircraft were able to perform zig-zag survey manoeuvres close to the Tiwi islands. However, the light winds also made the position of the Hector outflow uncertain. Both aircraft observed extensive cirrus decks covering an area of approximately 60,000 square kilometers just north of Darwin. Evidently, cirrus cloud remnants of Hector, and other sea-breeze initiated convection of the afternoon (see Fig. 13), had coalesced to form a nearly uniform deck between 12 and $16 \mathrm{~km}$ altitude, with much thinner ribbons of cloud disconnected from the main deck at altitudes up to $18 \mathrm{~km}$.

\subsection{Survey flights on 23 November}

Flight planning for all flights and in particular the survey flights was supported by a suite of forecast tools including standard and upper level weather charts prepared by KNMI, the Lancaster cirrus forecast mentioned earlier, backward and forward trajectory calculations using Lagranto (Wernli and Davies, 1997), and domain filling backward trajectories using the CLaMS model (Konopka et al., 2007) to determine the origin of airmasses.

The main goal of the mission on 23 November was the detailed probing of the rather quiescent TTL above the Arafura Sea including remote and in situ sampling of cirrus near the cold point tropopause (Fig. 14). Figure $9 \mathrm{~b}$ indicates that cloud cover over the Arafura Sea was the lowest of the whole campaign. Both the Falcon and M55 therefore flew long north-east oriented legs towards the equator perpendicular to the mean flow expected to be north-westerly in the TTL. A north-south section of the M55 and Falcon flight levels in terms of altitude and potential temperature is shown in Fig. 15. Flying back and forth along the same line twice, the M55 sampled the tropopause region at four different levels, two within the TTL at about $360 \mathrm{~K}(\sim 15 \mathrm{~km}$ pressure
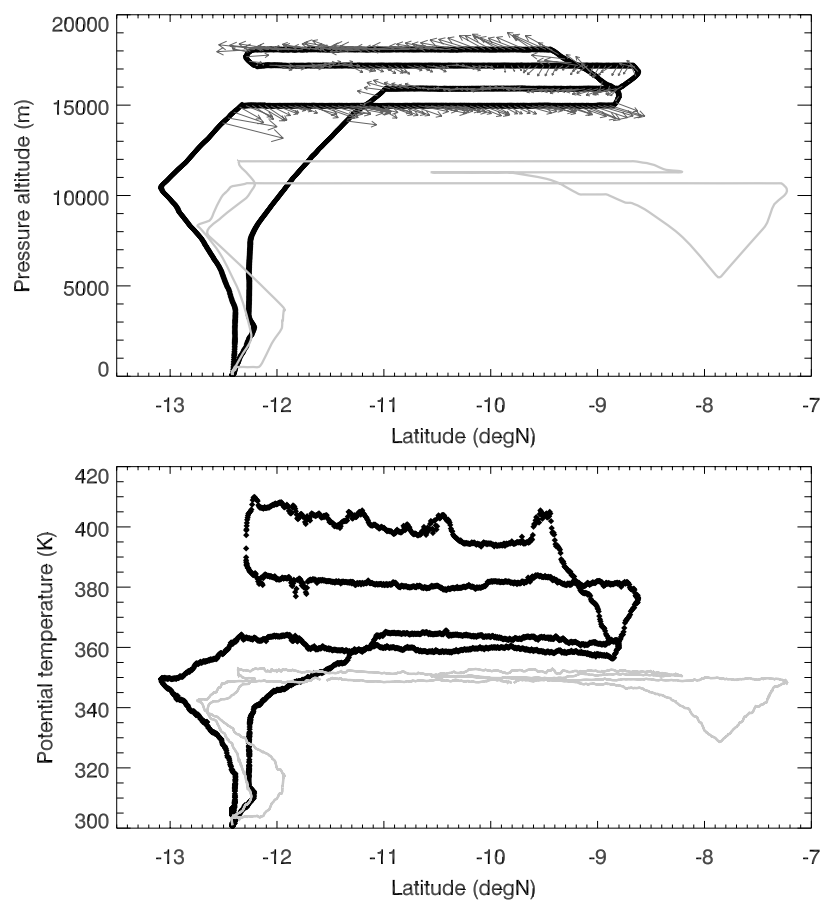

Fig. 15. North-south section of M55 (black and colors) and Falcon (grey) flight altitude (top) and potential temperature (bottom) on 23 November.

altitude) and $365 \mathrm{~K}(\sim 16 \mathrm{~km})$, one at or slightly above the cold point tropopause $(\sim 17 \mathrm{~km})$, and one level well above at $400-410 \mathrm{~K}(\sim 18 \mathrm{~km})$.

As shown by the wind arrows in Fig. 15 the flow situation was quite peculiar with north-westerly winds at $15 \mathrm{~km}$ and $17 \mathrm{~km}$ but opposite winds in between at $16 \mathrm{~km}$ and above at $18 \mathrm{~km}$, indicative of a wave (amplitude about $6 \mathrm{~m} / \mathrm{s}$ ). This wave was neither present in the ECMWF analysis nor in the radiosonde observations at Darwin at 09:30 LT (cf. Fig.5a). Extremely dry air (1.5-2 ppm) was measured by the FISH Lyman- $\alpha$ instrument (Zöger et al., 1999) onboard the M55 between $380 \mathrm{~K}$ and $390 \mathrm{~K}$ near the cold point tropopause (not shown). Since potential temperature surfaces are generally rising towards the equator at these levels, temperatures tend to decrease on constant pressure flight legs towards the equator (cf. Fig. 3). On the second highest pressure level, however, the coldest conditions were observed in the middle of the leg between $10^{\circ} \mathrm{S}$ and $11^{\circ} \mathrm{S}$ where the air was also the driest. North of $10^{\circ} \mathrm{S}$ the FISH $\mathrm{H}_{2} \mathrm{O}$ data became highly variable at the lower two levels suggesting the presence of ice particles, confirmed by measurements of the Multiwavelength Aerosol Scatterometer (MAS) which measures the light emitted by three laser diodes at different wavelengths and backscattered from aerosols and cloud particles (Adriani et al., 1997; Cairo et al., 2004). This flight will thus be particularly interesting to study dehydration processes in the TTL. The close association of the low water vapor concentrations 


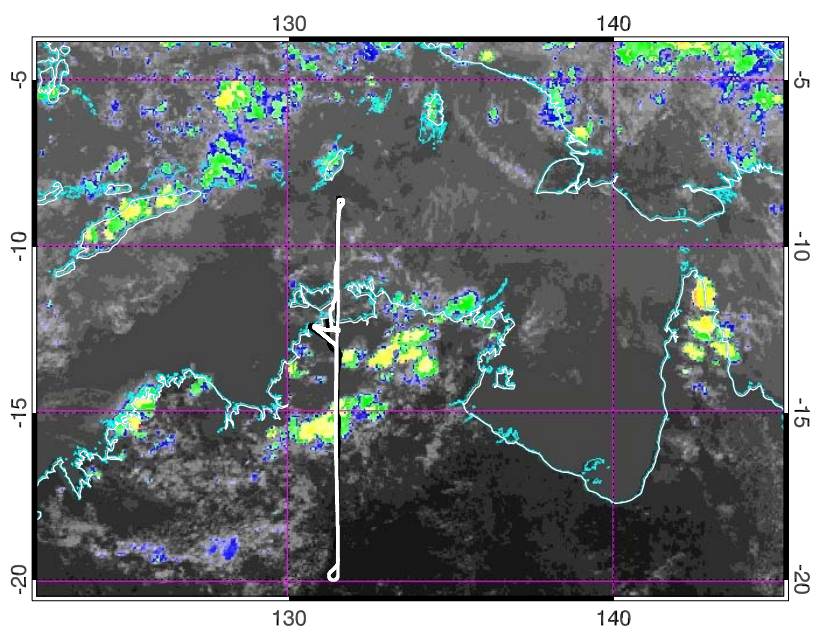

Fig. 16. Flight paths of M55 (white) and Falcon (black) on 29 November overlaid on GMS-5 satellite image valid at about 06:30 UTC (16:00 LT).

with the cold phase of the Kelvin wave visible in Fig. 5b will be demonstrated in a forthcoming study where measured humidities will be compared with saturation vapor pressures at the coldest temperatures along the calculated back trajectories (Brunner et al., manuscript in preparation, 2008). According to that analysis the dry air masses sampled on this flight had encountered a very cold tropopause 2-3 days earlier in the equatorial cold trap region. As seen in Fig. 14 the Falcon extended its flight towards the active monsoon region in the north where it was able to probe the anvil of an oceanic thunderstorm with a top at about $17 \mathrm{~km}$. Convective activity was also present in the southern part of the domain. Before 14:30 LT (05:00 UTC) it concentrated on the Tiwis while after 15:00 LT (05:30 UTC) it was becoming more intense in the Darwin area.

A moderate Hector developed on this day (see also Fig. 8) whose anvil clouds extended up to $\sim 17.5 \mathrm{~km}$ as observed by both the Falcon and M55 Lidars, somewhat higher than the oceanic systems. The two narrow temperature drops near $11.8^{\circ} \mathrm{S}$ and $380 \mathrm{~K}$ (Fig. 15, lower panel) occurred directly above a Hector overshoot as seen in the data of the downward pointing Lidar MAL (Cairo et al., 2004) and were associated with a $40 \%$ increase in nucleation mode particles (diameters $<6 \mathrm{~nm}$ ) measured with the Condensation Particle Counter System COPAS (Curtius et al., 2005), indicative of new particle formation.

\subsection{Survey flights on 29 November}

On 29 November the main target was again the characterization of the TTL and, in addition, a detailed profiling in the lower stratosphere up to aircraft ceiling altitude. In contrast to 23 November the TTL was highly perturbed by a number of MCS that developed over the Top End as seen
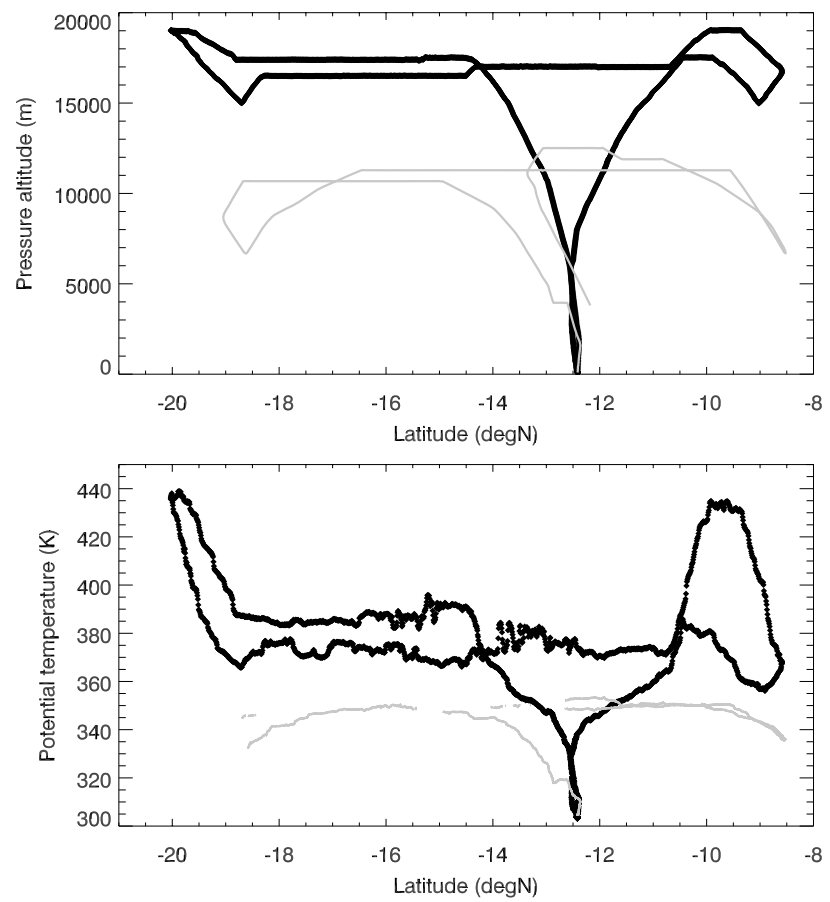

Fig. 17. North-south section of M55 (black) and Falcon (grey) flight altitude (top) and potential temperature (bottom) on 29 November.

in Fig. 16. In the morning the coastal area around Darwin and the Tiwis were overcast due to the remainders of a large MCS which had been active overnight. Convection therefore started further inland rather than along the sea breeze front as on other days. Several large and long-lived complexes built up (Figs. 16 and 8), their anvils soon covering the whole area of the Top End. The Falcon and M55 flew extended northsouth transects along $131^{\circ} 30^{\prime} \mathrm{E}$. As shown in Fig. 17, the M55 made two vertical profiles down to $15 \mathrm{~km}(360 \mathrm{~K})$ and up to $20 \mathrm{~km}(440 \mathrm{~K})$ at the northern and southern extremes of this transect, presumably inside and outside of the "tropical pipe" (Plumb, 1996), respectively, as indicated by largely different tracer-tracer correlations. On their first southward leg the Falcon and M55 had to cross a line of active thunderstorm development near $15^{\circ}-16^{\circ} \mathrm{S}$ (see Fig. 16). The Falcon managed to pass in between two updraft cores while the M55 flew over the eastern edge of the core region at a (geometric) altitude of $17.7 \mathrm{~km}$ some 20 min after the Falcon.

At this position and again two hours later at $13^{\circ}-14^{\circ} \mathrm{S}$ when the M55 passed over a second, even more active line further north, the M55 encountered gravity wave activity triggered by the storms. This is visible in Fig. 17 as fluctuations in potential temperature at the respective positions. Temperature exhibited peak-to-peak variations of about $5 \mathrm{~K}$ while pressure (top panel) stayed fairly constant. The COPAS measurements again indicate formation of new particles, probably triggered by these waves (not shown). North 


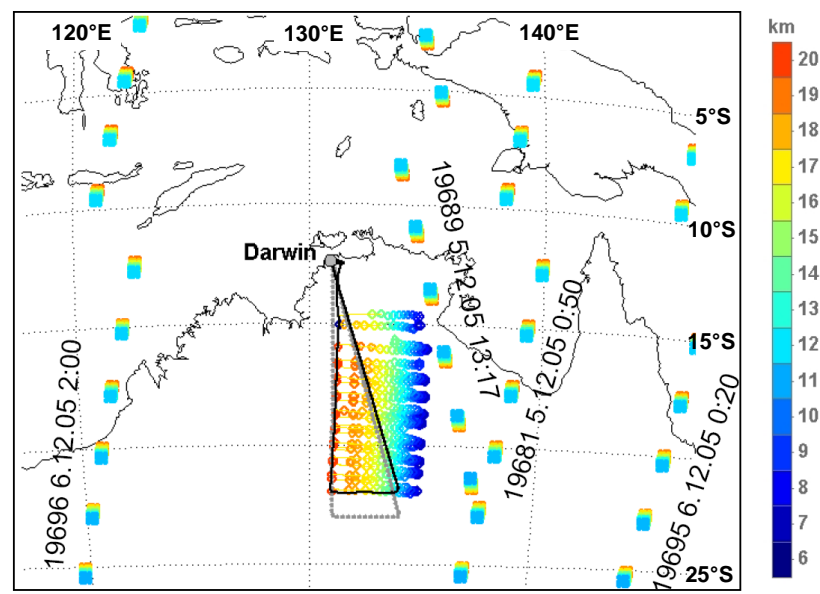

Fig. 18. Flight path of the Geophysica (black line) and Falcon (grey line) on 5 December. Colored symbols are the tangent heights of the limb scans of MIPAS-STR. The line of sights of the CRISTANF and MARSCHALS limb sounders are similar. Also shown are the tangent points of MIPAS limb scans from the temporally closest Envisat satellite overpasses. Satellite orbits are labelled by orbit number and date/time.

of about $15^{\circ} 30^{\prime} \mathrm{S}$ the Falcon Lidar observed thick anvil cirrus between 15 and $18 \mathrm{~km}$ altitude from the active MCS. The M55 was mostly flying inside these layers. At about $16^{\circ} 30^{\prime} \mathrm{S}$ three distinct cirrus layers were seen instead of a single thick layer which may afford the excellent opportunity to study cirrus and convective outflow of different origin and at different stages of ageing.

\subsection{Remote sensing flight on 5 December}

The flight mission on 5 December was optimized for remote sensing from the M55 by the thermal infrared limb sounders CRISTA-NF and MIPAS-STR and the microwave limb sounder MARSCHALS. The two aircraft basically followed a triangular path south of Darwin over the Australian continent. Figure 18 shows the map of the flight patterns of the M55 (black) and the Falcon (grey) with the geo-location of the tangent points of MIPAS-STR analyzed scans during the western leg. The sequences during the eastern leg are similar, but towards the west. In the southernmost leg, the M55 descended to $14 \mathrm{~km}$ to enable intercomparison of the limb sounders with in-situ measurement made on this aircraft. The M55 flew the triangle clockwise while the Falcon flew anti-clockwise to obtain the best overlap in space and time between its in-situ and Lidar measurements and the remote measurements from the M55. The first part of the flight was made before sunrise to get optimal conditions for the Lidar. The flight was planned to probe as long as possible in cloud-free conditions to enable profiling by the limb sounders into the TTL and down into the troposphere. The Lidar onboard the Falcon detected a 4-5 km thick cir- a)

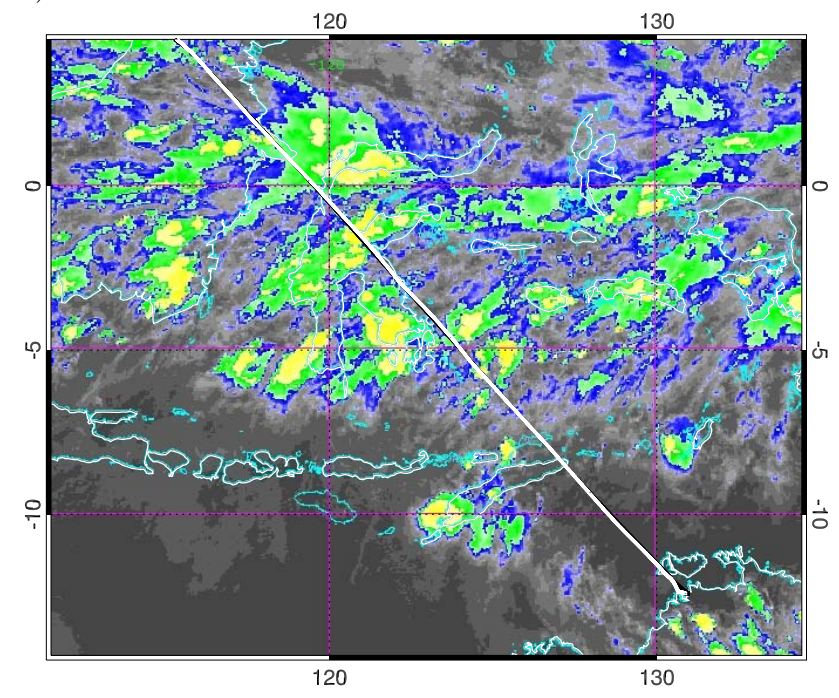

b)

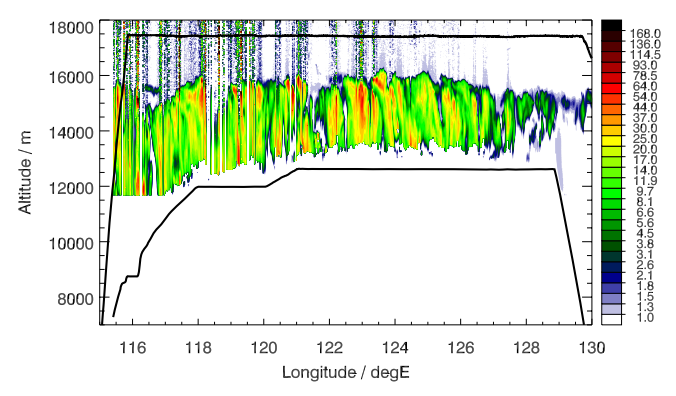

Fig. 19. (a) Transfer flight paths from Brunei into Darwin of M55 (white curve) and Falcon (black curve, mostly below white curve) overlaid on GMS-5 satellite image of 12 November 2005, 09:00 UTC. The Falcon flew between 06:00 and 10:00 UTC, the M55 between 10:00 and 14:30 UTC. (b) $532 \mathrm{~nm}$ backscatter ratios (parallel polarization) measured by the DLR differential absorption Lidar (DIAL). Flight paths of the Falcon (bottom line) and M55 (upper line) are overlaid. The $\mathrm{x}$-axis (longitude) is roughly aligned with that of the satellite image.

rus deck on both legs between Darwin and approximately $19^{\circ} 30^{\prime} \mathrm{S}$ reaching up to $17 \mathrm{~km}$. South of $19^{\circ} 30^{\prime} \mathrm{S}$, the TTL was nearly cloud-free except for sporadic subvisible cirrus at the cold point tropopause. The cloud top heights of the cirrus deck were consistently detected by the limb sounders from the M55. In the southernmost parts, retrievals deep into the troposphere were achieved.

\subsection{Transfer flights into and out of Darwin}

As mentioned earlier, transfer flights were an integral part of the campaign. Here, only the two flights from Brunei to Darwin (12 November) and back (9-10 December) are presented as they provided additional sampling of the tropical environment around Darwin. The flight paths overlaid on selected satellite images are shown in Figs. 19 and 20 together 
with $532 \mathrm{~nm}$ backscatter ratios measured by the DIAL Lidar on the Falcon. On the way to Darwin the Lidar was pointing upwards and on the way back downwards, in order to do a complete profiling (in particular of water vapor) throughout the depth of the troposphere and TTL. These two flights provided invaluable probing of the equatorial region downstream of the cold trap (cf. Fig. 2b). As the M55 was carrying several remote sensing instruments on the transfer flights, a flight altitude in the lower stratosphere was selected and the tropopause region scanned from above.

The meteorological situation was largely different on the two flights. On the transfer to Darwin on 12 November, the flight domain was almost completely covered with anvil cirrus outflow. The cirrus deck was strongly structured due to the merging of outflows from numerous storms but was rather sharply limited to a relatively low top at $16 \mathrm{~km}$ altitude. Approaching Darwin over the Arafura Sea, the cirrus became much thinner but was still present despite the seemingly clear area in the IR satellite image.

On the return flight taking place in the early morning convective activity was much weaker as suggested by Fig. 20a. The cloud layers observed by the Lidar below the Falcon flight path (Fig. 20b) perfectly match the positions of clouds in the satellite picture. The MAL Lidar on the M55 (not shown) detected a compact cirrus layer between $127^{\circ} \mathrm{E}$ (when MAL was switched on) and $122^{\circ} \mathrm{E}$ reaching almost to the flight level at $17.5 \mathrm{~km}$, thus more than $1 \mathrm{~km}$ higher than on the first flight. On the second half of the leg to Brunei, conversely, MAL and DIAL were probing a virtually cloudfree troposphere from the surface to $17.5 \mathrm{~km}$. The remote sensing instruments thus encountered ideal conditions to retrieve trace gas profiles deep into the equatorial troposphere.

\section{Origin of air masses in the TTL and lower strato- sphere}

Air parcel trajectories provide useful insight into the recent history and origin of the sampled air masses which will be related to their chemical signatures. 10-day backward trajectories were started every $10 \mathrm{~s}(\sim 2 \mathrm{~km})$ along the Falcon and M55 flight tracks using the trajectory tool Lagranto (Wernli and Davies, 1997) based on 3-h ECMWF three-dimensional winds (6-h analyzes plus 3- and 9-h forecasts in between). In addition to the trajectory position, temperature, humidity and potential vorticity were traced along the trajectories to characterize the physical air mass histories. In this section, we only present a brief analysis of the trajectories started from the M55 flight tracks above the $200 \mathrm{hPa}$ level representative of the TTL and the lower stratosphere around Darwin. Since trajectories are based on model resolved 3-D winds, subgridscale transport by convection is not resolved. The trajectories can therefore be considered to represent the large-scale history of the background environment rather than of air parcels injected locally by deep convection. a)

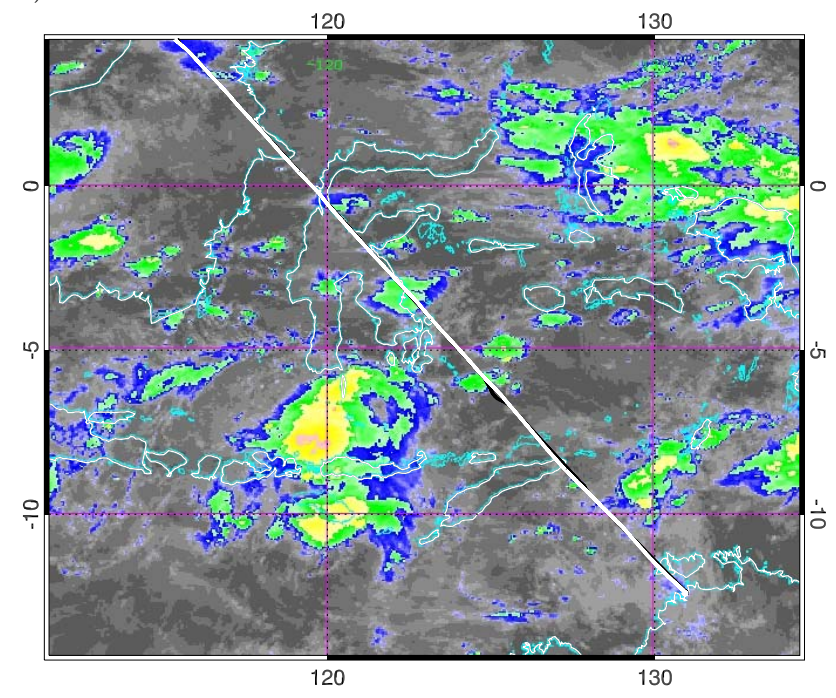

b)

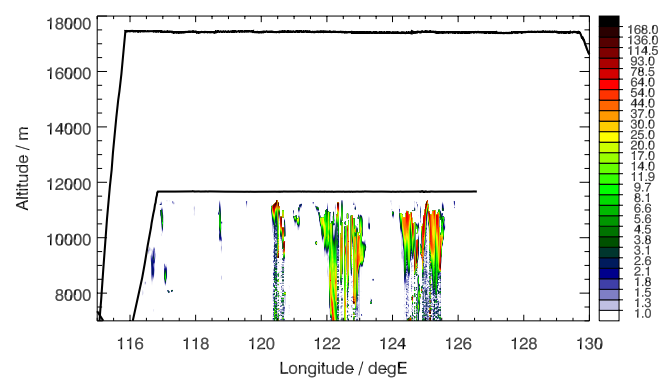

Fig. 20. (a) Transfer flight paths out of Darwin back to Brunei of M55 (white curve) and Falcon (black curve, mostly below white curve) overlaid over GMS-5 satellite image valid of 9 December, 21:00 UTC. The Falcon flight was between about 22:00 and 02:00 UTC, the M55 flight between 20:00 and 01:00 UTC. (b) Same as Fig. 19b but for 9 December. Note that the Lidar was pointed downwards from the Falcon track on this flight.

As mentioned in Sect. 2.1 the origin of air masses sampled in the tropopause region depended on the position of the upper level ridge axis. Figures 21 and 22 demonstrate that this led to a distinct separation in origin between the first four (16-25 November) and the last four local flights (29 November-5 December). During the first half of the campaign air masses primarily originated over the equatorial and Northern Hemisphere Western Pacific. They approached Darwin from the northeast thereby passing through the cold trap region (cf. Fig. 2b) where they were potentially dehydrated to low water vapor mixing ratios. The lower panel in Fig. 21 suggests that these air masses often experienced substantial upward transport, potentially from the marine boundary layer. This is supported by very low $\mathrm{CO}$ and $\mathrm{O}_{3}$ concentrations measured in the TTL on these flights, in particular on 16 November. The Hector flight on 19 November included a transect to the south because air of different origin was expected there. Figure 21 confirms that this air had a 

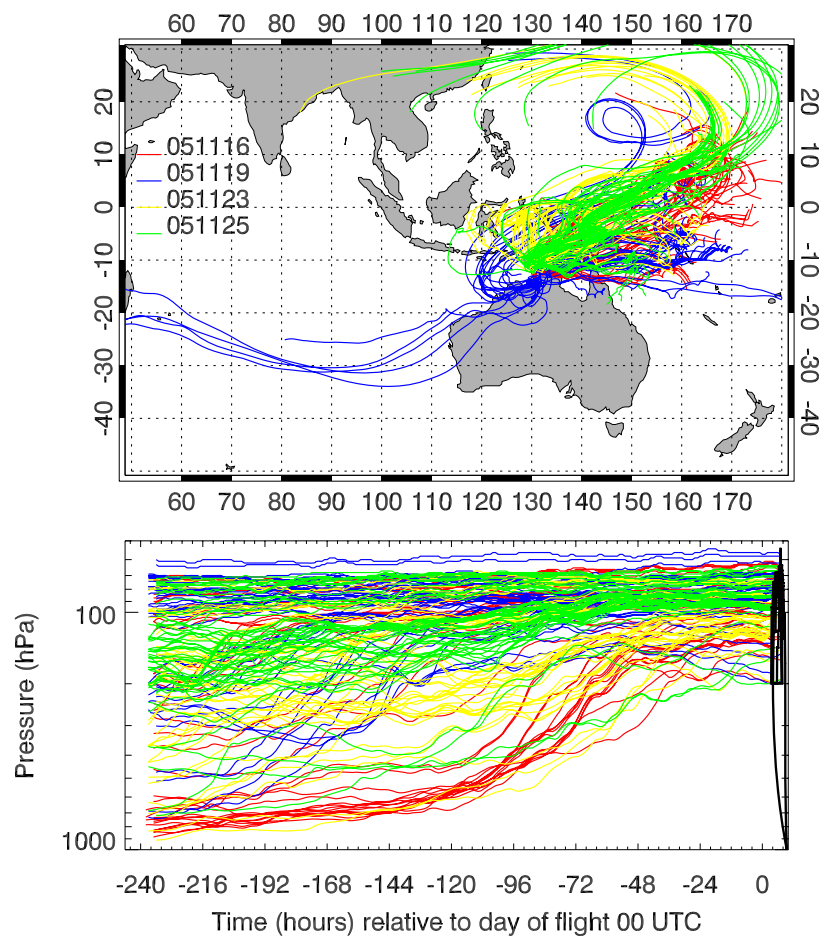

Fig. 21. Origin of air masses sampled by Geophysica in the upper troposphere and lower stratosphere $(p<200 \mathrm{hPa})$ on the first four local flights $(16,19,23$ and 25 November). The 10-day backward trajectories were calculated based on 3-h wind fields of ECMWF. Only trajectories started every 5 min along the flight tracks are shown. (a) Horizontal map, (b) Pressure versus time relative to the day of the flight.

distinctly different origin over the subtropical Indian Ocean. Air masses in the lower stratosphere mostly originated from the east or north-east and had travelled only small distances of typically $2000-3000 \mathrm{~km}$ within 10 days.

During the second half of the campaign the air originated over the equatorial Indian Ocean as well as over Southern Hemisphere subtropical and middle latitudes (Fig. 22). These air masses typically followed an anticyclonic path over the Indian Ocean and approached Darwin from the south thereby passing over the Australian continent. $\mathrm{CO}$ and $\mathrm{O}_{3}$ concentrations in the TTL were on average distinctly higher on these flights compared to the first four local flights. Measurements of aerosols, CO, and ozone taken by the Dornier aircraft of ACTIVE suggest that the boundary layer was largely influenced by biomass burning over northern Australia in November 2005 (Allen et al., 2008). Convective upward transport from the Australian boundary layer thus likely contributed to the enhanced $\mathrm{CO}$ and ozone concentrations observed in the TTL.
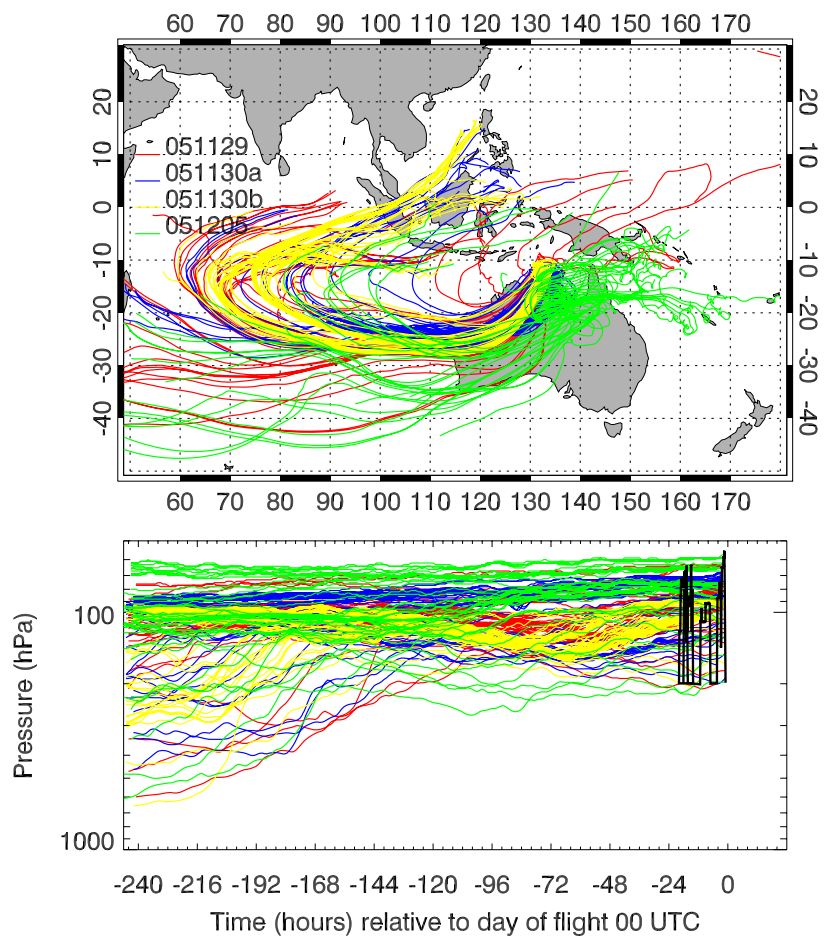

Fig. 22. Same as Fig. 21 but for the last four local flights (29 November, 2 x 30 November, 5 December).

\section{Summary and conclusions}

A tropical aircraft measurement campaign was conducted in the framework of the European integrated project SCOUTO3 at Darwin, Australia in November/December 2005. The campaign aimed at studying the mechanisms of transport through the TTL and into the stratosphere, and more specifically the role of deep convection versus large-scale transport, details of cirrus formation and dehydration, and the fate of very short lived substances.

The campaign took place during a near neutral phase of ENSO and no major tropical wave disturbance was present. Cloudiness near Darwin was close to average (weakly above) when compared with a 20 year climatology. The campaign was executed in the pre-monsoon season characterized by easterly low level winds and a pronounced diurnal cycle in thunderstorm activity and precipitation. The monthly mean position of the (Southern Hemisphere) subtropical jet was shifted equatorward in November 2005 and a series of Rossby wave breaking events at the jet affected Darwin between 19 and 25 November inducing a period of strong westerly winds at mid-levels $(600-150 \mathrm{hPa})$ and a few days of unusual (yet weak) westerlies at the surface. Consequently, thunderstorms developed under largely variable conditions in terms of steering (direction of storm motion), vertical shear, and direction of anvil outflow. CAPE levels were in the range 1000 to $3000 \mathrm{~J} / \mathrm{kg}$ typical for this region and time of the year, 
with the larger values occurring only on and after 30 November. Thunderstorm vigor showed only little relation with CAPE except that development was largely suppressed on days when no or very little CAPE was present.

Detailed probing of the thunderstorm system Hector, which develops over the Tiwi Islands almost daily in the early afternoon, was carried out on five out of eight local flights, two of which being co-ordinated with the ACTIVE campaign. Anvil tops were typically located at 17 to $17.5 \mathrm{~km}$ altitude close to the cold point tropopause (cf. Fig. 9b) which usually coincided with a strong increase in static stability. The M55 Geophysica mainly sampled above the anvil tops to investigate the effect of convective overshoots on hydration/dehydration of the tropopause region and injection of trace species, while the Falcon probed with its Lidar the structure of the anvil and other cirrus clouds and assisted in guiding the M55. Two local survey flights allowed for extensive sampling of the tropical tropopause layer and the tropical lower stratosphere. Parts of these flights were dedicated to study tropopause cirrus which were ubiquitous during the campaign. Together with the transfer flights into and out of Darwin these flights provide invaluable data on the chemical and physical structure of the TTL and on the microphysical properties and composition of in situ formed cirrus thus laying out the foundations for detailed process studies.

The large-scale origin of airmasses encountered in the TTL was different for the flights before and after 28 November. During the first half of the campaign, the air originated from the equatorial to northern subtropical Pacific and partly from the Northern Hemisphere. Strong ascent of these air masses suggests a significant contribution of clean marine boundary layer air. Once lofted to the upper troposphere, the air was exposed to the very low temperatures in the Maritime Continent cold trap region and thus potentially experienced significant dehydration. During the second half, the air originated from the equatorial Indian Ocean and Indonesia, or was trapped in the Southern Hemisphere subtropical jet.

While this paper provides a general overview of the meteorological context and a roadmap for the campaign, detailed analyzes of the measurements and process studies are presented in other papers in this special issue.

Acknowledgements. We would like to acknowledge the pilots of the two aircraft, the technical staff, and the flight planning teams (in particular Michael Volk, Geraint Vaughan, Martin Streibel, Beiping Luo, Paul Fortuin, Gebhard Günther, Martin Riese, Cees Bloom, Thierry Corti) for their dedication and for turning the scientist's dreams into viable flight missions. The remote support from the meteorological forecasters Peter van Velthoven and Rinus Scheele at KNMI was much appreciated. We would further like to thank the logistic team (Stefano Balestri and Heinz Finkenzeller) for organizing and accompanying a successful and memorable campaign, the Darwin RAAF base and Charles Darwin University for their hospitality and logistic support, and the forecasters at the BoM regional forecast center for great assistance. ECMWF (in particular Adrian Simmons) is acknowledged for generating tailored products and for providing access to forecast data used extensively during the campaign. We are grateful to Matt Wheeler (BoM) for providing an analysis of equatorial wave activity during the campaign. This work has been supported by the European Community grant through the project SCOUT-O3 under contract COCE-CT-2004-505390.

Edited by: M. Dameris

\section{References}

Adriani, A., Cairo, F., Viterbini, M., Mandolini, S., Pulvirenti, L., and Di Donfrancesco, G.: Multiwavelength aerosol scatterometer for airborne experiments to study the optical properties of stratospheric aerosol, J. Atmos. Ocean. Technol., 16, 1329-1336, 1997.

Allen, G., Vaughan, G., Bower, K. N., Williams, P. I., Crosier, J., Flynn, M., Connolly, P., Hamilton, J. F., Lee, J. D., Saxton, J. E., Watson, N. M., Gallagher, M., Coe, H., Allan, J., Choularton, T. W., and Lewis, A. C.: Aerosol and trace-gas measurements in the Darwin area during the wet season, J. Geophys. Res., 113, D06306, doi:10.1029/2007JD008706, 2008.

Allen, G., Vaughan, G., Brunner, D., May, P., Heyes, W., Minnis, P., and Ayers, J. K.: Modulation of tropical convection by breaking Rossby waves, J. Geophys. Res., in press, 2009.

Bonazzola, M. and Haynes, P. H.: A trajectory-based study of the tropical tropopause region, J. Geophys. Res., 109, D20112, doi: 10.1029/2003JD004356, 2004.

Cairo, F., Adriani, A., Viterbini, M., Di Donfrancesco, G., Mitev, V., Matthey, R., Bastiano, M., Redaelli, G., Dragani, R., Ferretti, R., Rizi, V., Paolucci, T., Bernardini, L., Cacciani, M., Pace, G., and Fiocco, G.: Polar stratospheric clouds observed during the airborne polar experiment-geophysica aircraft in Antarctica (APE-GAIA) campaign, J. Geophys. Res., 109, D07204, doi: 10.1029/2003JD003930, 2004.

Carbone, R. E., Wilson, J. W., Keenan, T. D., and Hacker, J. M.: Tropical island convection in the absence of significant tropography - Part I: Life cycle of diurnally forced convection, Mon. Weather Rev., 123, 3459-3480, 2000.

Chaboureau, J.-P., Cammas, J.-P., Duron, J., Mascart, P. J., Sitnikov, N. M., and Voessing, H.-J.: A numerical study of tropical crosstropopause transport by convective overshoots, Atmos. Chem. Phys., 7, 1731-1740, 2007, http://www.atmos-chem-phys.net/7/1731/2007/.

Corti, T., Luo, B. P., de Reus, M., Brunner, D., Cairo, F., Mahoney, M. J., Martucci, G., Matthey, R., Mitev, V., dos Santos, F. H., Schiller, C., Shur, G., Sitnikov, N. M., Spelten, N., Vössing, H. J., Borrmann, S., and Peter, T.: Unprecedented evidence for deep convection hydrating the tropical stratosphere, Geophys Res. Lett., 35, L10810, doi:10.1029/2008GL033641, 2008.

Crook, N. A.: Understanding Hector: The dynamics of island thunderstorms, Mon. Weather Rev., 129, 1550-1563, 2001.

Curtius, J., Weigel, R., Vössing, H.-J., Wernli, H., Werner, A., Volk, C.-M., Konopka, P., Krebsbach, M., Schiller, C., Roiger, A., Schlager, H., Dreiling, V., and Borrmann, S.: Observations of meteoric material and implications for aerosol nucleation in the winter Arctic lower stratosphere derived from in situ particle measurements, Atmos. Chem. Phys., 5, 3053-3069, 2005, http://www.atmos-chem-phys.net/5/3053/2005/. 
Danielsen, E. F.: A dehydration mechanism for the stratosphere, Geophys. Res. Lett., 9, 605-608, 1982.

Danielsen, E. F.: In situ evidence of rapid, vertical, irreversible transport of lower tropospheric air into the lower tropical stratosphere by convective cloud turrets and by larger-scale upwelling in tropical cyclones, J. Geophys. Res., 98, 8665-8681, 1993.

de Reus, M., Borrmann, S., Bansemer, A., Curtius, J., Frey, W., Heymsfield, A. J., Küerten, A., Ravegnani, F., Schiller, C., Sitnikov, N. M., Ulanovsky, A., and Weigel, R.: Evidence for ice particles in the tropical stratosphere from in-situ measurements, Atmos. Chem. Phys. Discuss., 8, 19313-19355, 2008, http://www.atmos-chem-phys-discuss.net/8/19313/2008/.

Drosdowsky, W.: Variability of the Australian Summer Monsoon at Darwin: 1957-1992, J. Climate, 9, 85-96, 1996.

Ern, M., Preusse, P., Krebsbach, M., Mlynczak, M. G., and Russell III, J. M.: Equatorial wave analysis from SABER and ECMWF temperatures, Atmos. Chem. Phys., 8, 845-869, 2008, http://www.atmos-chem-phys.net/8/845/2008/.

Fueglistaler, S., Wernli, H., and Peter, T.: Tropical troposphereto-stratosphere transport inferred from trajectory calculations, J. Geophys. Res., 109, D03104, doi:10.1029/2003JD004069, 2004.

Fueglistaler, S., Bonazzola, M., Haynes, P. H., and Peter, T.: Stratospheric water vapor predicted from the Lagrangian temperature history of air entering the stratosphere in the tropics, J. Geophys. Res., 110, D08107, doi:10.1029/2004JD005516, 2005.

Gary, B. L.: Mesoscale temperature fluctuations in the stratosphere, Atmos. Chem. Phys., 6, 4577-4589, 2006, http://www.atmos-chem-phys.net/6/4577/2006/.

Gettelman, A., Randel, W. J., Wu, F., and Massie, S. T.: Transport of water vapor in the tropical tropopause layer, Geophys. Res. Lett., 29, 1009, doi:10.1029/2001GL013818, 2002.

Gill, A. E.: Some simple solutions for heat induced tropical circulation, Q. J. Roy. Meteor. Soc., 106, 447-462, 1980.

Höpfner, M., von Clarmann, T., Fischer, H., et al.: Valiation of MIPAS $\mathrm{ClONO}_{2}$ measurements, Atmos. Chem. Phys., 7, 257281, 2007,

http://www.atmos-chem-phys.net/7/257/2007/.

Hoffmann, L., Weigel, K., Spang, R., Schroeder, S., Arndt, K., Lehmann, C., Kaufmann, M., Ern, M., Preusse, P., Stroh, F., and Riese, M.: CRISTA-NF measurements of water vapor during the SCOUT-O3 tropical aircraft campaign, J. Adv. Space Res., 43, 74-81, doi:10.1016/j.asr.2008.03.018, 2009.

Holland, G. J.: Interannual variability of the Australian summer monsoon at Darwin: 1952-82, Mon. Weather Rev., 114, 594604, 1986.

Holton, J. R. and Gettelman, A.: Horizontal transport and dehydration in the stratosphere, Geophys. Res. Lett., 28, 2799-2802, 2001.

Keenan, T. D. and Carbone, R. E.: A preliminary morphology of precipitation systems in tropoical northern Australia, Q. J. Roy. Meteor. Soc., 118, 283-326, 1992.

Keenan, T. D., Morton, B. R., Zhang, Y. S., and Nguyen, K.: Some characteristics of thunderstorms over Bathurst and Melville Islands near Darwin, Australia, Q. J. Roy. Meteor. Soc., 116, 11531172, 1990.

Keenan, T. D., Rutledge, S., Carbone, R., Wilson, J., Takahashi, T., May, P., Tapper, N., Platt, M., Hacker, J., Sekelsky, S., Moncrieff, M., Saito, K., Holland, G., Crook, A., and Gage, K.: The Maritime Continent Thunderstorm Experiment (MCTEX): Overview and some results, B. Am. Meteorol. Soc., 81, 2433-2455, 2000.

Kelly, K. K., Proffitt, M. H., Chan, K. R., Loewenstein, M., Podolske, J. R., Strahan, S. E., Wilson, J. C., and Kley, D.: Water-vapor and cloud water measurements over Darwin during the STEP 1987 tropical mission, J. Geophys. Res., 98, 87138723, 1993.

Kley, D., Schmeltekopf, A. L., Kelly, K., Winkler, R. H., Thompson, T. L., and McFarland, M.: Transport of water through the tropical tropopause, Geophys. Res. Lett., 9, 617-6203, 1982.

Konopka, P., G'ünther, G., Müeller, R., Santos, F. H., Schiller, C., Ulanovsky, A., Schlager, H., Volk, C. M., Viciani, S., Pan, L., McKenna, D. S., and Riese, M.: Mixing-driven troposphere to stratosphere transport (TST) across the TTL, Atmos. Chem. Phys., 7, 3285-3308, 2007, http://www.atmos-chem-phys.net/7/3285/2007/.

Krämer, M., Schiller, C., Voigt, C., Schlager, H., and Popp, P. J.: A climatological view of $\mathrm{HNO}_{3}$ partitioning in cirrus clouds, Q. J. Roy. Meteor. Soc., 134, 905-912, doi:10.1002/qj.253, 2008.

Levine, J. G., Braesicke, P., Harris, N. R. P., Savage, N. H., and Pyle, J. A.: Pathways and timescales for troposphere-tostratosphere transport via the tropical tropopause layer and their relevance for very short lived substances, J. Geophys. Res., 112, D04308, doi:10.1029/2005JD006940, 2007.

MacKenzie, A. R., Schiller, C., Peter, T., Adriani, A., Beuermann, J., Bujok, O., Cairo, F., Corti, T., DiDonfrancesco, G., Gensch, I., Kiemle, C., Krämer, M., Kröger, C., Merkulov, S., Oulanovsky, A., Ravegnani, F., Rohs, S., Rudakov, V., Salter, P., Santacesaria, V., Stefanutti, L., and Yushkov, V.: Tropopause and hygropause variability over the equatorial Indian Ocean during February and March 1999, J. Geophys. Res., 111, D18112, doi:0.1029/2005JD006639, 2006.

Madden, R. A. and Julian, P. R.: Detection of a 40-50 day oscillation in the tropical Pacific, J. Atmos. Sci., 28, 702-708, 1971.

Matsuno, T.: Quasi-geostrophic motions in the equatorial area, J. Met. Soc. Japan, 44, 25-43, 1966.

May, P. T. and Ballinger, A.: The statistical characteristics of convective cells in a monsoon regime (Darwin, Northern Australia), Mon. Weather Rev., 134, 82-92, 2006.

May, P. T., Allen, G., Vaughan, G., and Connolly, P.: Aerosol and thermodynamic effects on tropical cloud systems during TWPICE and ACTIVE, Atmos. Chem. Phys., 9, 15-24, 2009, http://www.atmos-chem-phys.net/9/15/2009/.

May, P. T., Mather, J. H., Vaughan, G., and Jakob, C.: Characterizing oceanic convective cloud systems: The Tropical Warm Pool International Cloud Experiment, B. Am. Meteorol. Soc., 89, 153-155, doi:10.1175/BAMS-89-2-153, 2008 b.

McBride, J. L. and Frank, W. M.: Relationships between stability and monsoon convection, J. Atmos. Sci., 56, 24-56, 1999.

Müller, S. C., Kämpfer, N., Feist, D. G., Haefele, A., Milz, M., Sitnikov, N., Schiller, C., Kiemle, C., and Urban, J.: Validation of stratospheric water vapour measurements from the airborne microwave radiometer AMSOS, Atmos. Chem. Phys., 8, 31693183, 2008, http://www.atmos-chem-phys.net/8/3169/2008/.

Newell, R. E. and Gould-Stewart, S.: A stratospheric fountain?, J. Atmos. Sci., 38, 2789-2796, 1981.

Nielsen, J. K., Larsen, N., Cairo, F., Di Donfrancesco, G., Rosen, J. M., Durry, G., Held, G., and Pommereau, J. P.: Solid particles in the tropical lowest stratosphere, Atmos. Chem. Phys., 7, 685- 
695, 2007,

http://www.atmos-chem-phys.net/7/685/2007/.

Plumb, R. A.: A "tropical pipe" model of stratospheric transport, J. Geophys. Res., 101, 3957-3972, 1996.

Ren, C., MacKenzie, A. R., Schiller, C., Shur, G., and Yushkov, V.: Diagnosis of processes controlling water vapour in the tropical tropopause layer by a Lagrangian cirrus model, Atmos. Chem. Phys., 7, 5401-5413, 2007, http://www.atmos-chem-phys.net/7/5401/2007/.

Ricaud, P., Barret, B., Attié, J.-L., Motte, E., Le Flochmoën, E., Teyssèdre, H., Peuch, V.-H., Livesey, N., Lambert, A., and Pommereau, J.-P.: Impact of land convection on tropospherestratosphere exchange in the tropics, Atmos. Chem. Phys., 7, 5639-5657, 2007,

http://www.atmos-chem-phys.net/7/5639/2007/.

Russell, P. B., Pfister, L., and Selkirk, H. B.: The Tropical Experiment of the Stratosphere-Troposphere Exchange Project (STEP): Science objectives, operations, and summary findings, J. Geophys. Res., 98, 8563-8590, 1993.

Rutledge, S. A., Williams, E. R., and Keenan, T. D.: The Down-Under Doppler and Electricity Experiment (DUNDEE): Overview and preliminary results, B. Am. Meteorol. Soc., 73, 3-16, 1992.

Schiller, C., Krämer, M., Afchine, A., Spelten, N. and Sitnikov, N.: The ice water content of Arctic, mid latitude and tropical cirrus, J. Geophys. Res., 113, D2408, doi:10.1029/2008JD010342, 2008

Selkirk, H. B.: The tropopause cold trap in the australian monsoon during STEP/AMEX in 1987, J. Geophys. Res., 98, 8591-8610, 1993.

Shaik, H. A. and Cleland, S. J.: The tropical circulation in the Australian/Asian region - November 2005 to April 2006, Aust. Meterol. Mag., 55, 219-230, 2006.

Sherwood, S. C. and Dessler, A. E.: A model for transport across the tropical tropopause, J. Atmos. Sci., 58, 765-779, 2001.

Spang, R., Hoffmann, L., Kullmann, A., Olschewski, F., Preusse, P., Knieling, P., Schroeder, S., Stroh, F., Weigel, K., and Riese, M.: High resolution limb observations of clouds by the CRISTA-NF experiment during the SCOUT-O3 tropical aircraft campaign, J. Adv. Space Res., 42, 1765-1775, doi:10.1016/j.asr.2007.09.036, 2007.
Stefanutti, L., MacKenzie, A. R., Balestri, S., Khattatov, V., Fiocco, G., Kyro, E., and Peter, T.: Airborne polar experiment - Polar ozone, leewaves, chemistry, and transport (APE-POLECAT: Rationale, road map and summary of measurements, J. Geophys. Res., 104, 23 941-23 959, 1999.

Vasic, V., Feist, D. G., Müller, S., and Kämpfer, N.: An airborne radiometer for stratospheric water vapor measurements at $183 \mathrm{GHz}$, IEEE T. Geosci. Remote Sens., 43, 1563-1570, doi: 10.1109/TGRS.2005.846860, 2005.

Vaughan, G., Schiller, C., MacKenzie, A. R., Bower, K., Peter, T., Schlager, H., Harris, N. R. P., and May, P. T.: SCOUTO3/ACTIVE: High-altitude aircraft measurements around deep tropical convection, B. Am. Meteorol. Soc., 89, 647-662, doi: 10.1175/BAMS-89-5-647, 2008.

Wang, P. H., Minnis, P., McCormick, M. P., Kent, G. S., and Skeens, K. M.: A 6-year climatology of cloud occurrence frequency from Stratospheric Aerosol and Gas Experiment II observations (1985-1990), J. Geophys. Res., 101, 29 407-29 429, 1996.

Wernli, H. and Davies, H. C.: A Lagrangian-based analysis of extratropical cyclones. Part I: The method and some applications, Q. J. Roy. Meteor. Soc., 123, 467-489, 1997.

Wheeler, M. and Kiladis, G. N.: Convectively coupled equatorial waves: Analysis of clouds and temperature in the wavenumberfrequency domain, J. Atmos. Sci., 56, 374-399, 1999.

Wheeler, M. C. and Hendon, H. H.: An all-season real-time multivariate MJO index: Development of an index for monitoring and prediction, Mon. Weather Rev., 132, 1917-1932, 2004.

Whiteway, J., Cook, C., Gallagher, M., Choularton, T., Harries, J., Connolly, P., Busen, R., Bower, K., Flynn, M., May, P., Aspey, R., and Hacker, J.: Anatomy of cirrus clouds: Results from the Emerald airborne campaigns, Geophys. Res. Lett., 31, L24102, doi:10.1029/2004GL021201, 2004.

Zöger, M., Afchine, A., Eicke, N., Gerhards, M.-T., Klein, E., McKenna, D. S., Möerschel, U., Tan, V., Woyke, T., and Schiller, C.: Fast in situ stratospheric hygrometers: A new family of balloon-borne and airborne Lyman- $\alpha$ photofragment fluorescence hygrometers, J. Geophys. Res., 104, 1807-1816, 1999. 